Published in final edited form as:

Inorg Chem. 2016 January 19; 55(2): 419-431. doi:10.1021/acs.inorgchem.5b01662.

\title{
Models of the $\mathrm{Ni}-\mathrm{L}$ and $\mathrm{Ni}-\mathrm{SI}{ }_{\mathrm{a}}$ States of the [NiFe]-Hydrogenase Active Site
}

\author{
Geoffrey M. Chambers ${ }^{\dagger, \ddagger}$, Mioy T. Huynh ${ }^{\dagger}$, Yulong $\mathrm{Li}^{\dagger}$, Sharon Hammes-Schiffer ${ }^{\dagger,},{ }^{\star}$, Thomas \\ B. Rauchfuss ${ }^{\dagger, \ddagger,{ }^{*} \text {, Edward Reijerse, and Wolfgang Lubitz }}{ }^{*}$ \\ $\dagger$ \\ $\ddagger$
}

\section{Abstract}

A new class of synthetic models for the active site of [NiFe]-hydrogenases are described. The $\mathrm{Ni}^{\mathrm{I} / \mathrm{II}}(\mathrm{SCys})_{2}$ and $\mathrm{Fe}^{\mathrm{II}}(\mathrm{CN})_{2} \mathrm{CO}$ sites are represented with $\left(\mathrm{RC}_{5} \mathrm{H}_{4}\right) \mathrm{Ni}^{\mathrm{I} / \mathrm{II}}$ and $\mathrm{Fe}^{\mathrm{II}}(\operatorname{diphos})(\mathrm{CO})$ modules, where diphos $=1,2-\mathrm{C}_{2} \mathrm{H}_{4}\left(\mathrm{PPh}_{2}\right)_{2}(\mathrm{dppe})$ or cis-1,2- $\mathrm{C}_{2} \mathrm{H}_{2}\left(\mathrm{PPh}_{2}\right)_{2}(\mathrm{dppv})$. The two bridging thiolate ligands are represented by $\mathrm{CH}_{2}\left(\mathrm{CH}_{2} \mathrm{~S}\right)_{2}{ }^{2-}\left(\mathrm{pdt}^{2-}\right), \mathrm{Me}_{2} \mathrm{C}\left(\mathrm{CH}_{2} \mathrm{~S}\right)_{2}{ }^{2-}\left(\mathrm{Me}_{2} \mathrm{pdt}^{2-}\right)$, and $\left(\mathrm{C}_{6} \mathrm{H}_{5} \mathrm{~S}\right)_{2}{ }^{2-}$. The reaction of $\mathrm{Fe}(\mathrm{pdt})(\mathrm{CO})_{2}(\mathrm{dppe})$ and $\left[\left(\mathrm{C}_{5} \mathrm{H}_{5}\right)_{3} \mathrm{Ni}_{2}\right] \mathrm{BF}_{4}$ affords $\left[\left(\mathrm{C}_{5} \mathrm{H}_{5}\right) \mathrm{Ni}(\mathrm{pdt}) \mathrm{Fe}(\mathrm{dppe})-(\mathrm{CO})\right] \mathrm{BF}_{4}\left([\mathbf{1 a}] \mathrm{BF}_{4}\right)$. Monocarbonyl [1a $] \mathrm{BF}_{4}$ features an $S=0 \mathrm{Ni}^{\mathrm{II}} \mathrm{Fe}^{\mathrm{II}}$ center with five-coordinated iron, as proposed for the $\mathrm{Ni}_{-} \mathrm{SI}_{\mathrm{a}}$ state of the enzyme. One-electron reduction of $[\mathbf{1 a}]^{+}$affords the $S=1 / 2$ derivative $[\mathbf{1 a}]^{0}$, which, according to density functional theory (DFT) calculations and electron paramagnetic resonance and Mössbauer spectroscopies, is best described as a Ni ${ }^{\mathrm{I}} \mathrm{Fe}^{\mathrm{II}}$ compound. The $\mathrm{Ni}^{\mathrm{I}} \mathrm{Fe}^{\mathrm{II}}$ assignment matches that for the Ni-L state in $[\mathrm{NiFe}]$-hydrogenase, unlike recently reported $\mathrm{Ni}^{\mathrm{II}} \mathrm{Fe}^{\mathrm{I}}$-based models. Compound $[\mathbf{1 a}]^{0}$ reacts with strong acids to liberate 0.5 equiv of $\mathrm{H}_{2}$ and regenerate $[\mathbf{1 a}]^{+}$, indicating that $\mathrm{H}_{2}$ evolution is catalyzed by $[\mathbf{1 a}]^{0}$. DFT calculations were used to investigate the pathway for $\mathrm{H}_{2}$ evolution and revealed that the mechanism can proceed through two isomers of $[\mathbf{1 a}]^{0}$ that differ in the stereochemistry of the $\mathrm{Fe}$ (dppe)CO center. Calculations suggest that protonation of [1a $]^{0}$ (both isomers) affords $\mathrm{Ni}^{\mathrm{III}}-\mathrm{H}-\mathrm{Fe}^{\mathrm{II}}$ intermediates, which represent mimics of the Ni-C state of the enzyme.

\section{Graphical abstract}

\footnotetext{
“Corresponding Authors: shs3@illinois.edu. rauchfuz@illinois.edu. wolfgang.lubitz@cec.mpg.de.

Notes

The authors declare no competing financial interest.

Supporting Information

The Supporting Information is available free of charge on the ACS Publications website at DOI: 10.1021/acs.inorg-chem. 5 b01662. Experimental details, calculated reduction potentials, $\Delta v_{\mathrm{CO}}$, a comparison of crystal and DFT-optimized structures using different DFT functionals, calculated relative free energies, barriers, and spin densities for all intermediates in the catalytic cycles, extended discussion of the $\mathrm{Ni}-\mathrm{Fe}$ bond, discussion of the TS and isomerization for $[\mathbf{1 a}]^{+}$and $[\mathbf{1 a}]^{0}$, and coordinates and energies of all optimized structures (PDF)

$\mathrm{X}$-ray crystallographic data in CIF format (CIF)
} 


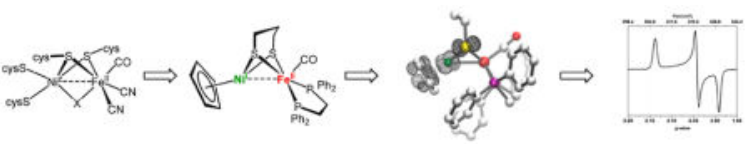

\section{INTRODUCTION}

Hydrogenases are enzymes that catalyze the oxidation of hydrogen and reduction of protons at high rates and low overpotentials, reactions that are potentially useful for clean energy applications. ${ }^{1-4}$ Hydrogenases are classified into three main families according to the metals in their active site: $[\mathrm{Fe}]-,[\mathrm{FeFe}]-$, and $[\mathrm{NiFe}]$-hydrogenases. ${ }^{5,6}$ These enzymes are oxygensensitive but the $[\mathrm{NiFe}]-$ hydrogenases can recover from oxygen poisoning. ${ }^{8,9}$ Model compounds have been useful in elucidating catalytic mechanisms or atom identity, notably with $[\mathrm{FeFe}]$-hydrogenases. ${ }^{7,10}[\mathrm{FeFe}]$-hydrogenase models are fairly advanced and have strong resemblance and relevance to the enzymatic system. ${ }^{3,4,11}$ In contrast, models of the oxygentolerant $[\mathrm{NiFe}]$-hydrogenases are less mature, and comparisons to the enzymatic system are sometimes less applicative. . $^{3,4,12,13}$

The $[\mathrm{NiFe}]$-hydrogenase active site features a $\left[\mathrm{Ni}(\mathrm{SCys})_{4}\right]^{z}$ center linked through two thiolate bridges to an $\mathrm{Fe}(\mathrm{CN})_{2}(\mathrm{CO})$ center (Figure 1). In the absence of a third bridging ligand, the geometry at nickel resembles that of $\mathrm{SF}_{4}$, while iron is square-pyramidal. The active states of the enzyme differ in three ways: (i) the oxidation state of the Ni center, (ii) the presence/absence of a hydride ligand bridging the two metals, and (iii) the state of protonation of at least one terminal cysteinyl thiolate. In contrast to the fluctuating oxidation states at the nickel center, iron appears to remain low-spin $\mathrm{Fe}^{\mathrm{II}}$ throughout all of the known states of the enzyme active site.

Beyond complementing our understanding of the enzyme, synthetic models could underpin the development of new catalysts for the processing of $\mathrm{H}_{2} \cdot{ }^{1,2}$ The possibility of connecting synthetic complexes to enzyme states was established with [(dppe)Ni(pdt)( $\mu$ $\left.\mathrm{H}) \mathrm{Fe}(\mathrm{CO})_{3}\right]^{+.14,21}$ A related nickel-iron hydride $\left[(\text { amine })_{2} \mathrm{Ni}(\mathrm{SR})_{2}(\mu-\mathrm{H}) \mathrm{FeL}_{3}\right]^{+}$catalyzes the reduction of redox dyes by $\mathrm{H}_{2}$, a characteristic assay for the hydrogenases. ${ }^{15}$ With a $\mathrm{Ni}^{\mathrm{II}}-\mathrm{H}-$ $\mathrm{Fe}^{\mathrm{II}}$ core, these synthetic complexes represent early models for the Ni-R state of the protein, despite discrepancies (Table 1). ${ }^{16}$

Concurrent with the development of these diamagnetic models, ${ }^{21,22}$ efforts have been made to replicate the paramagnetic states of the enzyme. The two most prominent paramagnetic states are Ni-C and Ni-L. Invoked in all catalytic mechanisms is Ni-C, ${ }^{6,7,23-25}$ which features a hydride bridging the $\mathrm{Ni}^{\mathrm{III}}$ and $\mathrm{Fe}^{\mathrm{II}}$ centers. No synthetic analogues of this nickel(III) hydride have been detected, but this paper provides a first glimpse of a synthetic model. With a NiI $\mathrm{Fe}^{\mathrm{II}}$ core, $\mathrm{Ni}-\mathrm{L}$ is typically generated by low-temperature photolysis of $\mathrm{Ni}$ C, and recent evidence points to its role in catalysis. ${ }^{26,27}$ These $S=1 / 2$ states deviate most strongly from the conventional chemistry of dimetal systems and therefore offer the greatest opportunity for the discovery of fundamentally new reactivity. The first reported $S=1 / 2$ $\mathrm{NiFe}$ complex was $\left[(\text { diphos }) \mathrm{Ni}(\mathrm{pdt}) \mathrm{Fe}-(\mathrm{CO})_{2} \mathrm{~L}\right]^{+}$. Spectroscopic, crystallographic, and computational analyses show, however, that these cations are described as $\mathrm{Ni}^{\mathrm{II}} \mathrm{Fe}^{\mathrm{I}}$ 
derivatives, ${ }^{20,28}$ not $\mathrm{Ni}^{\mathrm{I}} \mathrm{Fe}^{\mathrm{II}}$ as assigned to the Ni-L state of the enzyme. ${ }^{16}$ The lapse is a consequence of the $\mathrm{Fe}(\mathrm{CO})_{2} \mathrm{~L}$ center, which stabilizes $\mathrm{Fe}^{\mathrm{I}}$. In the present report, the $\mathrm{Fe}(\mathrm{CO})_{2} \mathrm{~L}$ center is replaced by the $\mathrm{Fe}($ diphos$)(\mathrm{CO})$ module, which more strongly stabilizes $\mathrm{Fe}^{\mathrm{II} .22}$

One of the weaknesses in the first generation of active-site model is a high reorganization energy upon oxidation at nickel. ${ }^{21}$ This work addresses this weakness. Redox at the nickel centers typically induces changes in the coordination geometry, such that $\mathrm{Ni}^{\mathrm{I}}$ species (cf. Ni$\mathrm{L}$ ) are tetrahedral and $\mathrm{Ni}^{\mathrm{II} / \mathrm{III}}$ species (cf. Ni-SI $\mathrm{a}, \mathrm{Ni}-\mathrm{R}, \mathrm{Ni}-\mathrm{C}$ ) are square-planar (Figure 2). In contrast, the $\mathrm{NiFe}$ active site changes only subtly as it converts among catalytic states. ${ }^{16,27}$ To minimize reorganizational barriers, the $[\mathrm{Ni}(\text { diphos })]^{z}$ site is replaced by $\left[\left(\mathrm{C}_{5} \mathrm{H}_{5}\right) \mathrm{Ni}\right]^{z}$. The $\left[\left(\mathrm{C}_{5} \mathrm{H}_{5}\right) \mathrm{Ni}(\mathrm{SR})_{2}\right]^{z}$ center has the advantage that its geometry is relatively insensitive to redox, in contrast to Ni(dppe)(SR) ${ }_{2}$-based models (Figure 2). Not only does the hapticity of $\mathrm{C}_{5} \mathrm{H}_{5}$ not change, but crystallographic studies ${ }^{29-31}$ show that the $\mathrm{Ni}^{-} \mathrm{C}_{5} \mathrm{H}_{5}$ distances are relatively invariant $(<0.12 \AA)$ for $\mathrm{Ni}^{\mathrm{I}}, \mathrm{Ni}^{\mathrm{II}}$, and $\mathrm{Ni}^{\mathrm{III}}\left(\mathrm{C}_{5} \mathrm{H}_{5}\right)$ compounds.

\section{RESULTS AND DISCUSSION}

\section{Models for Ni-SI: Synthesis and Structure}

The reaction of $\mathrm{Fe}(\mathrm{pdt})(\mathrm{CO})_{2}(\mathrm{dppe})$ and $\left[\left(\mathrm{C}_{5} \mathrm{H}_{5}\right)_{3} \mathrm{Ni}_{2}\right] \mathrm{BF}_{4}$ in nitromethane affords $\left[\left(\mathrm{C}_{5} \mathrm{H}_{5}\right) \mathrm{Ni}(\mathrm{pdt}) \mathrm{Fe}(\mathrm{dppe})(\mathrm{CO})\right] \mathrm{BF}_{4}\left([\mathbf{1} \mathbf{a}] \mathrm{BF}_{4}\right.$; eq 1$)$ as a dark-red powder. The derivatives $\left[\left(\mathrm{C}_{5} \mathrm{H}_{5}\right) \mathrm{Ni}(\mathrm{pdt}) \mathrm{Fe}(\mathrm{dppv})-(\mathrm{CO})\right] \mathrm{BF}_{4}\left([\mathbf{1} \mathbf{b}] \mathrm{BF}_{4}\right),\left[\left(\mathrm{C}_{5} \mathrm{H}_{5}\right) \mathrm{Ni}\left(\mathrm{Me}_{2} \mathrm{pdt}\right) \mathrm{Fe}(\mathrm{dppe})(\mathrm{CO})\right]-\mathrm{BF}_{4}$ $\left([\mathbf{1 c}] \mathrm{BF}_{4}\right)$, and $\left[\left(\mathrm{CH}_{3} \mathrm{C}_{5} \mathrm{H}_{4}\right) \mathrm{Ni}(\mathrm{pdt}) \mathrm{Fe}(\mathrm{dppe})(\mathrm{CO})\right] \mathrm{BF}_{4}\left([\mathbf{1 d}] \mathrm{BF}_{4}\right)$, where dppv = cis-1,2$\mathrm{C}_{2} \mathrm{H}_{2}\left(\mathrm{PPh}_{2}\right)_{2}$ and $\mathrm{Me}_{2} \mathrm{pdt}^{2-}=\mathrm{Me}_{2} \mathrm{C}\left(\mathrm{CH}_{2} \mathrm{~S}^{-}\right)_{2}$, were also prepared using the appropriate nickel and iron precursors. These salts are similar to $[\mathbf{1 a}] \mathrm{BF}_{4}$ in terms of their reactivity and spectroscopic properties. The reaction of $\mathrm{Fe}(\mathrm{pdt})(\mathrm{CO})_{2}(\mathrm{dppe})$ and $\left[\left(\mathrm{C}_{5} \mathrm{H}_{5}\right)_{3} \mathrm{Ni}_{2}\right] \mathrm{BF}_{4}$ proceeds via an intermediate with $v_{\mathrm{CO}}=1980 \mathrm{~cm}^{-1}$ that converts to [1a $]^{+}$. We assign this intermediate band to the dicarbonyl complex trans $-\left[\left(\mathrm{C}_{5} \mathrm{H}_{5}\right) \mathrm{Ni}(\mathrm{pdt}) \mathrm{Fe}(\mathrm{dppe})(\mathrm{CO})_{2}\right]-\mathrm{BF}_{4}$. The disappearance of the intermediate band follows first-order decay (Figures S45 and S46). When the reaction progress is monitored by ${ }^{31} \mathrm{P}$ NMR spectroscopy, the iron precursor is consumed within ca. 5 min and two new singlet resonances are observed, one of which corresponds to the product $[\mathbf{1 a}]^{+}$. Additionally, electrospray ionization mass spectrometry (ESI-MS) of the reaction mixture indicates the presence of the molecular cation $\left[\left(\mathrm{C}_{5} \mathrm{H}_{5}\right) \mathrm{Ni}(\mathrm{pdt}) \mathrm{Fe}(\mathrm{dppe})-(\mathrm{CO})_{2}\right]^{+}$. These observations are consistent with the rapid attachment of " $\left(\mathrm{C}_{5} \mathrm{H}_{5}\right) \mathrm{Ni}^{+}$" to the two isomers of the iron dithiolate. The cis-carbonyl derivative appears to release $\mathrm{CO}$ rapidly, whereas the isomer with trans-CO ligands is somewhat persistent. 


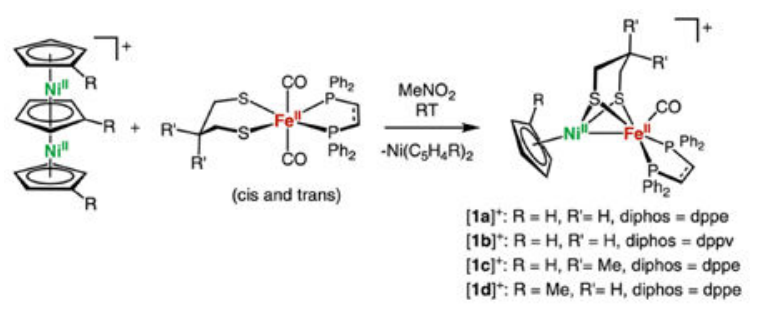

Purified compounds $[\mathbf{1 a}-\mathbf{1 d}] \mathrm{BF}_{4}$ display a single $\tilde{v_{\mathrm{CO}}}$ band in the range of $1940-1951 \mathrm{~cm}^{-1}$, consistent with the presence of one isomer. These values are similar to those observed in $\mathrm{Ni}$ $\mathrm{SI}_{\mathrm{a}}$, which range from 1927 to $1947 \mathrm{~cm}^{-1}$ (Table 2). ${ }^{6}$

The structure of $[\mathbf{1 a}]^{+}$was confirmed by X-ray crystallography. The $\mathrm{Ni}-\mathrm{Fe}$ distance is 2.5145(4) $\AA$ (Figure 3). Although the enzyme in the $\mathrm{SI}_{\mathrm{a}}$ state has not been characterized crystallographically, it is generally assumed that the $\mathrm{Ni}-\mathrm{Fe}$ distance is $\sim 2.6 \AA$ in all active states. ${ }^{6}$ The stereochemistry of the $\mathrm{FeL}_{2}(\mathrm{CO})$ site is biomimetic in the sense that $\mathrm{CO}$ occupies an apical site, and the two Lewis basic phosphine ligands are approximately trans to the sulfur centers of the thiolates.

The ${ }^{31} \mathrm{P}$ NMR spectra of complexes [1a- $\left.\mathbf{1 d}\right] \mathrm{BF}_{4}$ are simple, exhibiting only a single resonance, indicating chemically equivalent phosphorus centers or a dynamic process. The diphosphine in complexes [1a-1d] $\mathrm{BF}_{4}$ is only observed in the dibasal arrangement, whereas other $\mathrm{Fe}$ (dithiolate)-(diphosphine)CO compounds have been shown to adopt both a dibasal and an apical-basal arrangement. ${ }^{33}$ The phosphorus centers remain NMR-equivalent at -90 ${ }^{\circ} \mathrm{C}$, suggesting either an exceptionally low barrier for isomerization or the presence of a single isomer. In the IR spectrum, only a single isomer is observed, which, like the enzyme's active site, has both donor ligands in basal positions.

The reaction of cis,cis- $\mathrm{Fe}(\mathrm{SPh})_{2}(\mathrm{CO})_{2}(\mathrm{dppv})$ and $\left[\left(\mathrm{C}_{5} \mathrm{H}_{5}\right)_{3} \mathrm{Ni}_{2}\right] \mathrm{BF}_{4}$ gave the dicarbonyl $\left[\left(\mathrm{C}_{5} \mathrm{H}_{5}\right) \mathrm{Ni}(\mathrm{SPh})_{2} \mathrm{Fe}-(\mathrm{dppv})(\mathrm{CO})_{2}\right] \mathrm{BF}_{4}\left([2 \mathbf{b C O}] \mathrm{BF}_{4}\right)$, isolated as dark, almost black, microcrystals. Its ${ }^{1} \mathrm{H}$ NMR spectrum exhibits only one $\left(\mathrm{C}_{5} \mathrm{H}_{5}\right)$ signal, and an $\mathrm{AB}$ quartet pattern in the ${ }^{31} \mathrm{P}$ NMR spectrum, indicating low symmetry. The structure was confirmed crystallographically (Figure S53). The Ni-Fe distance is 3.308(1) $\AA$, indicating a noncovalent interaction. The stereochemistry at iron is identical with the precursor, wherein all ligands are cis. The $\mu$-SPh groups are diaxial.

Upon treatment with $\mathrm{Me}_{3} \mathrm{NO}$, the dicarbonyl readily decarbonylated to give $[\mathbf{2 b}] \mathrm{BF}_{4}$, isolated as a black solid. The IR spectrum of $[\mathbf{2 b}]^{+}$in a $\mathrm{CH}_{2} \mathrm{Cl}_{2}$ solution displays a single $\tilde{v_{\mathrm{CO}}}$ band at $1956 \mathrm{~cm}^{-1}$, versus 2042 and $2002 \mathrm{~cm}^{-1}$ observed for the precursor. The monocarbonyl cation, $[\mathbf{2 b}]^{+}$, decomposes gradually in a $\mathrm{CH}_{2} \mathrm{Cl}_{2}$ solution. However, the complex is stable in $\mathrm{MeCN}$, and the $\tilde{v_{\mathrm{CO}}}$ band shifts $22 \mathrm{~cm}^{-1}$ to higher energies, suggesting the formation of an adduct. The ${ }^{31} \mathrm{P}$ NMR spectrum of [2/b] $]^{+}$exhibits a singlet at $\delta 78.8$. Under $1 \mathrm{~atm}$ of $\mathrm{CO}, \mathrm{MeCN}$ solutions of $[\mathbf{2 b}]^{+}$partially convert back to $[\mathbf{2 b C O}]^{+}$. In contrast, $[\mathbf{1 a}]^{+}$is not reactive toward $\mathrm{CO}$. 


\section{Electrochemistry}

The cyclic voltammetry of [1a] $\mathrm{BF}_{4}$ in dichloromethane $\left(\mathrm{CH}_{2} \mathrm{Cl}_{2}\right)$ is very rich (Figure 4). Compounds $[\mathbf{1 b}-\mathbf{1 d}]^{+}$produce similar voltammograms (Table 3 ). Compounds $[\mathbf{1 a}-\mathbf{1 d}]^{+}$ exhibit an irreversible oxidation near $+0.65 \mathrm{~V}$ and a reversible one-electron reduction near $-1.20 \mathrm{~V}$, all versus $\mathrm{Fc}^{0 /+}$. Additionally, a quasi-reversible reduction is observed near -2.15 $\mathrm{V}$, which becomes fully reversible when in tetrahydrofuran (THF) with $\left[\mathrm{Bu}_{4} \mathrm{~N}\right] \mathrm{B}\left(\mathrm{C}_{6} \mathrm{H}_{3}-3,5-\right.$ $\left.\left(\mathrm{CF}_{3}\right)_{2}\right)_{4}$ as the electrolyte. An irreversible reduction wave is generated at ca. $0.0 \mathrm{~V}$ versus $\mathrm{Fc}^{0 /+}$ following the irreversible oxidation.

The redox couples in the different derivatives are relatively similar. The reversible couple is most affected by $\mathrm{Me}_{2}$ pdt substitution. With $\Delta v_{\mathrm{CO}}=3 \mathrm{~cm}^{-1}$ (Table 1), the donor properties of $\mathrm{pdt}^{2-}$ and $\mathrm{Me}_{2} \mathrm{pdt}^{2-}$ are similar in this system, and the difference in the potential of the $\mathrm{Ni}^{\mathrm{II}} \mathrm{Fe}^{\mathrm{II}} / \mathrm{Ni}^{\mathrm{I}} \mathrm{Fe}{ }^{\mathrm{II}}$ redox couple may be due to the steric effects of the methyl groups. The reversible reduction in complexes $[\mathbf{1 a}-\mathbf{1 d}]^{+}$shifts to more positive potentials by $50 \mathrm{mV}$ upon replacement of $\left(\mathrm{C}_{5} \mathrm{H}_{5}\right)$ for $\mathrm{CH}_{3} \mathrm{C}_{5} \mathrm{H}_{4}$. This effect suggests that the reduction is nickelcentered, generating a $\mathrm{Ni}^{\mathrm{I}} \mathrm{Fe}{ }^{\mathrm{II}}$ species. $\mathrm{CH}_{3} \mathrm{C}_{5} \mathrm{H}_{4}$ substitution most affected the oxidation observed at $\approx 0.75 \mathrm{~V}$, shifting this couple by $-80 \mathrm{mV}$, whereas other substitutions only generate a $20-30 \mathrm{mV}$ effect. This observation suggests that oxidation is nickel-centered. The reduction near $-2 \mathrm{~V}$ is negligibly affected by the nickel-based ligands and is proposed to be an iron-centered reduction, generating a $\mathrm{Ni}^{\mathrm{I}} \mathrm{Fe}^{\mathrm{I}}$ species.

Density functional theory (DFT) was used to calculate the potentials associated with the couples $[\mathbf{1 a}-\mathbf{1 d}]^{2+/+},[\mathbf{1 a}-\mathbf{1 d}]^{+/ 0}$, and $[\mathbf{1 a}-\mathbf{1 d}]^{0 /-}$. The potentials were calculated relative to [1a] $\mathrm{BF}_{4}$ and are provided in Table 3. The experimental trends are well reproduced by the calculations. The $\mathrm{BF}_{4}{ }^{-}$ions were not included in the calculations, which may cause deviations between the calculated and experimental values. The reduction potentials were also calculated for an alternative geometry optimization scheme, as well as using different functionals, and these results are provided in Tables S1 and S2.

\section{Models for Ni-L: Synthesis and Structure}

The reduced species $[\mathbf{1 a}-\mathbf{1 d}]^{0}$ and $[\mathbf{2} \mathbf{b}]^{0}$ were produced on a preparative scale by treatment with $\left(\mathrm{C}_{5} \mathrm{H}_{5}\right)_{2} \mathrm{Co}\left(E^{0}=-1.23 \mathrm{~V}\right.$; eq 2$)$.

$$
\left[\left(\mathrm{C}_{5} \mathrm{H}_{5}\right) \mathrm{Ni}(\mathrm{SR})_{2} \mathrm{Fe}(\text { diphos })(\mathrm{CO})\right] \mathrm{BF}_{4}+\left(\mathrm{C}_{5} \mathrm{H}_{5}\right)_{2} \mathrm{Co} \rightarrow\left(\mathrm{C}_{5} \mathrm{H}_{5}\right) \mathrm{Ni}(\mathrm{SR})_{2} \mathrm{Fe}(\text { diphos })(\mathrm{CO})+\left[\left(\mathrm{C}_{5} \mathrm{H}_{5}\right)_{2} \mathrm{Co}\right] \mathrm{BF}_{4}
$$

Purified samples [1a-1d $]^{0}$ and $[\mathbf{2 b}]^{0}$ were isolated as black, air-sensitive solids. Reduction of $[\mathbf{1 a}-\mathbf{1 d}]^{+}$and $[\mathbf{2 b}]^{+}$, a Ni ${ }^{\mathrm{II}} \mathrm{Fe}^{\mathrm{II}} / \mathrm{Ni}^{\mathrm{I}} \mathrm{Fe} \mathrm{II}^{\mathrm{II}}$ couple, shifts $v_{\mathrm{CO}}$ by ca. $40 \mathrm{~cm}^{-1}$ to around 1900 $\mathrm{cm}^{-1}$. A similar change is observed for the reduction of $\left[(\mathrm{dppe}) \mathrm{Ni}(\mathrm{pdt}) \mathrm{Fe}(\mathrm{CO})_{3}\right]^{+}, \mathrm{a}$ $\mathrm{Ni}^{\mathrm{II}} \mathrm{Fe} / \mathrm{A} / \mathrm{Ni}^{\mathrm{I}} \mathrm{Fe}^{\mathrm{I}}$ couple $\left(\Delta v_{\mathrm{CO}} \approx 35 \mathrm{~cm}^{-1}\right.$ for this tricarbonyl). ${ }^{20}$ Oxidation state changes centered at iron typically shift $v_{\mathrm{CO}}$ by ca. $100 \mathrm{~cm}^{-1}$ as observed for [(dppe)Pt(pdt) $\left.\mathrm{Fe}(\mathrm{CO})_{3}\right]^{+/ 0}$, a $\mathrm{Pt}^{\mathrm{II}} \mathrm{Fe}^{\mathrm{I}} / \mathrm{Pt}^{\mathrm{II}} \mathrm{Fe}^{0}$ couple. ${ }^{21}$ For the Ni-L state of the $[\mathrm{NiFe}]-$ hydrogenases, the values of $v_{\mathrm{CO}}$ range from 1911 (Desulfovibrio vulgaris Miyazaki $\mathrm{F}$ ) ${ }^{34}$ to $1862 \mathrm{~cm}^{-1}$ (Aquifex aeolicus) (Table 4). ${ }^{26,35}$ 
X-ray crystallographic analysis confirmed that the solid-state structures of $[\mathbf{1 a}]^{0}$ (Figure 5) and $[\mathbf{1 a}]^{+}$(Figure 3 ) are very similar. The principal changes in these structures are in the coordination sphere of nickel, which suggests that the couple [1a $]^{+/ 0}$ involves a nickelcentered reduction. The $\mathrm{Ni}_{-} \mathrm{C}_{5} \mathrm{H}_{5}$ and $\mathrm{Ni}-\mathrm{S}$ bonds elongate by about $5 \%$, while the $\mathrm{Fe}-$ ligand bond lengths remain virtually unchanged. The Ni-Fe distance shortens by $\sim 0.1 \AA$ to 2.4593(5) $\AA$, which is well within the sum of the atomic radii [2.56(6) $\AA$ ], indicating the presence of metal-metal bonding. Although there are no crystallographic data on the metalmetal-bonded Ni-L state of the enzyme, DFT calculations predict this distance to be 2.56 $\AA .{ }^{36}$ The observed structural changes are consistent with reduction at the nickel center in the transformation of $[\mathbf{1 a}]^{+}$to $[\mathbf{1 a}]^{0}$. The DFT-optimized structures of $[\mathbf{1 a}]^{+}$and $[\mathbf{1 a}]^{0}$ were in excellent agreement with the crystal structures (Table 5).

DFT analysis of the spin density was used to determine the site of reduction of $[\mathbf{1 a}-\mathbf{1 d}]^{+}$. The plot of the spin density for $[\mathbf{1 a}]^{0}$ (Figure 6 ) reveals that the unpaired electron resides primarily on the nickel center, with some delocalization on the pdt ${ }^{2-}$ and $\left(\mathrm{C}_{5} \mathrm{H}_{5}\right)^{-}$ligands but no significant delocalization on the iron. This result is consistent with the $\mathrm{Ni}^{\mathrm{I}} \mathrm{Fe}^{\mathrm{II}}$ assignment and the experimentally observed elongation of the Ni-ligand bonds upon reduction of $[\mathbf{1 a}]^{+}$.

The spin densities for the reduced species $[\mathbf{1 a}-\mathbf{1 d}]^{0}$ and $[\mathbf{2 b}]^{0}$ are given in Table 6 and consistently indicate a nickel-based reduction across all species. As observed for related nickel-iron dithiolate complexes, ${ }^{20,21}$ the spin densities are not significantly affected by the conformation of the pdt ligand. Furthermore, the calculations also predict that an iron-based reduction would require potentials of $0.2-0.4 \mathrm{~V}$ more negative than the experimentally observed nickel-based reduction potentials (Table S1).

Crystallographic analysis revealed that the structure of $[\mathbf{2 b}]^{0}$ differs strongly from that of $[\mathbf{1 a}]^{0}$ (Figure 7). Specifically, the iron center is inverted such that the CO ligand is poised between the iron and nickel centers (eq 3 ). The $\mathrm{CO}$ ligand is not bridging, as indicated by the long Ni-CO distance of $2.878 \AA$. The DFT-optimized geometry of [2 $\mathbf{2 b}]^{0}$ is in good agreement with the crystal structure (Table S8), and the Ni-CO distance is calculated to be $2.916 \AA$ A . Furthermore, $\tilde{v_{\mathrm{CO}}}$ for $[\mathbf{2 b}]^{0}$ is calculated to be $1911 \mathrm{~cm}^{-1}$ for the rotated structure, close to the observed value of $1915 \mathrm{~cm}^{-1}$. A small shoulder at approximately $1900 \mathrm{~cm}^{-1}$ is also observed in the spectrum and may result from the presence of a second rotamer. For $[\mathbf{2 b}]^{0}$, the isomer in which the CO ligand is apical, as in the structure of $[\mathbf{2 b}]^{+}$, is calculated to be higher in free energy by $3.70 \mathrm{kcal} \mathrm{mol}^{-1}$ compared to the isomer in which the $\mathrm{CO}$ ligand is poised between the iron and nickel centers. This free energy difference is consistent with the crystal structure of $[\mathbf{2 b}]^{0}$ featuring an inverted iron center.

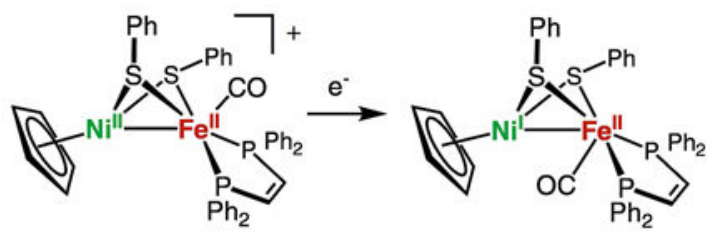




\section{Models for Ni-L: Spectroscopy}

The X-band continuous-wave electron paramagnetic resonance (CW-EPR) spectrum of $[\mathbf{1 a}]^{0}$ is rhombic with $g$ values of $1.991,2.042$, and 2.138. No hyperfine coupling was detected (Figure 8). Spectra of $[\mathbf{1} \mathbf{b}-\mathbf{1 d}]^{0}$ are very similar to that of $[\mathbf{1} \mathbf{a}]^{0}$ (Table 7). The absence of significant ${ }^{31} \mathrm{P}$ hyperfine coupling is consistent with a nickel-centered radical, indicating that these compounds feature $\left(\mathrm{C}_{5} \mathrm{H}_{5}\right) \mathrm{Ni}^{\mathrm{I}}$ centers. Large ${ }^{31} \mathrm{P}$ hyperfine coupling was observed in related mixed-valence compounds containing iron(I) phosphine centers, e.g., $\left[(\mathrm{CO})_{2}\left(\mathrm{PR}_{3}\right) \mathrm{Fe}(\mathrm{pdt}) \mathrm{Ni}\right.$-(diphosphine $\left.)\right]^{+.20,28}$

Q-band ENDOR experiments were conducted to probe the spin distribution in the mixedvalence state. Consistent with the absence of any hyperfine splitting in the EPR spectrum, the ${ }^{31} \mathrm{P}$ hyperfine couplings were found to be very small $(\sim 11 \mathrm{MHz}$; Table 8 and Figure S10). Several proton hyperfine contributions were detected using ENDOR spectroscopy with hyperfine splittings ranging from 4 to $11 \mathrm{MHz}$ (Figure S9). The variant of complex $[\mathbf{1 a}]^{0}$ carrying $\mathrm{C}_{5} \mathrm{D}_{5}\left(\left[\mathbf{1 a}-d_{5}\right]^{0}\right)$ in place of $\mathrm{C}_{5} \mathrm{H}_{5}$ afforded a greatly simplified ${ }^{1} \mathrm{H}$ ENDOR pattern with the largest proton coupling ( $11 \mathrm{MHz}$ ) being absent (Figure S8), indicating that the spin density is localized on the nickel and its immediate coordination sphere. The weaker ${ }^{1} \mathrm{H}$ couplings observed for $\left[\mathbf{1 a}-d_{5}\right]^{0}$ are assigned to two equivalent methylene protons of $\mathrm{pdt}^{2-}$. These observations are consistent with DFT analysis, which shows that the spin density in $[\mathbf{1 a}]^{0}$ and $[\mathbf{2 b}]^{0}$ is primarily localized on the $\left(\mathrm{C}_{5} \mathrm{H}_{5}\right) \mathrm{Ni}(\mathrm{pdt})$ center (Figure 6 and Table 6). Despite the different stereochemistry at iron, at least in the solid state, and the presence of $\mathrm{SPh}^{-}$versus $\mathrm{R}_{2} \mathrm{pdt}^{2-}$, the EPR spectra of all mixed-valence compounds are similar.

The $\left[\mathbf{1 a}-d_{5}\right]^{0}$ orientation-selective ENDOR patterns (Figure S8) could be simulated with one proton hyperfine interaction (originating from two equivalent $\mathrm{pdt}^{2-}$ methylene protons). Although, in principle, up to eleven protons $\left[\mathrm{C}_{5} \mathrm{H}_{5}+\mathrm{CH}_{2}\left(\mathrm{CH}_{2} \mathrm{~S}\right)_{2}\right]$ could contribute to the ${ }^{1} \mathrm{H}$ ENDOR spectra of $[\mathbf{1 a}]^{0}$, only one additional contribution, assigned to the $\left(\mathrm{C}_{5} \mathrm{H}_{5}\right)$ ligand, could be distinguished and evaluated (see Figure S9). It can be assumed that the proton(s) with their hyperfine tensors approximately aligned with the $g$-tensor axes lead to the strongest contributions along these axes in the orientation-selective ENDOR spectra. The hyperfine tensors of the $\mathrm{C}_{5} \mathrm{H}_{5}$ protons that are not aligned with the $g$-tensor axes give rise to additional weaker features in the ENDOR spectra (Figure S9), which have not been simulated. The simulation parameters of the $\mathrm{C}_{5} \mathrm{H}_{5}{ }^{-}$and $\mathrm{pdt}^{2-}\left(\mathrm{CH}_{2} \mathrm{~S}\right)$ contributions are given in Table 8.

The measured Mössbauer spectra of $[\mathbf{1 a}-\mathbf{1 c}]^{0}$ and the corresponding cations are quite similar (see Figures S1-S6). All exhibit low isomer shifts of $\delta=0.11-0.14 \mathrm{~mm} \mathrm{~s}^{-1}$ and small quadrupole splittings of $\Delta E_{\mathrm{q}}=0.72-1.15 \mathrm{~mm} \mathrm{~s}^{-1}$ (Table 9). The Mössbauer data are in agreement with a low-spin iron in all complexes. Consistent with other data in this paper, the spectra support the oxidation-state assignments of $\mathrm{Ni}^{\mathrm{II}} \mathrm{Fe}^{\mathrm{II}}$ for compounds $[\mathbf{1 a}-\mathbf{1 c}] \mathrm{BF}_{4}$ and $\mathrm{Ni}^{\mathrm{I}} \mathrm{Fe}^{\mathrm{II}}$ for compounds $[\mathbf{1 a}-\mathbf{1 c}]^{0}$. The isomer shifts observed in the $\mathrm{Ni}^{\mathrm{I}} \mathrm{Fe}^{\mathrm{II}}$ compounds $[\mathbf{1 a}-$ 1c $]_{0}$ are larger than the shift observed for the $\mathrm{Ni}^{\mathrm{II}^{\mathrm{II}}} \mathrm{Fe}^{\mathrm{I}}$ compound [(dppe) $\left.\mathrm{Ni}(\mathrm{pdt}) \mathrm{Fe}(\mathrm{CO})_{3}\right] \mathrm{BF}_{4}$ $\left(\delta=0.04 \mathrm{~mm} \mathrm{~s}^{-1}\right)$, while the quadrupole splittings are comparable $\left(\Delta E_{\mathrm{q}}=0.57\right){ }^{20}$ 
Mössbauer data for the [NiFe]-hydrogenases are sparse and suffer from difficulties in identifying and correcting for the dominating subspectra of the accessory FeS clusters. ${ }^{37,38}$ Isomer shifts in the range of $0.05-0.15 \mathrm{~mm} \mathrm{~s}^{-1}$ have been assigned to the iron center of the $[\mathrm{NiFe}]$ center. $^{39}$

The Mössbauer spectrum of $[\mathbf{1 a}]^{0}$ was further examined at high magnetic fields. This spectrum shows a very weak internal field contribution with an isotropic ${ }^{57} \mathrm{Fe}$ hyperfine coupling of $2 \mathrm{MHz}$ (Table 8 and Figure S7). For comparison, magnetic Mössbauer spectra of the $\mathrm{Fe}^{\mathrm{I}}$ center in the $\mathrm{H}_{\mathrm{OX}}$ state of the $[\mathrm{FeFe}]$-hydrogenase indicate ${ }^{57} \mathrm{Fe}$ hyperfine couplings in the range of $10-20 \mathrm{MHz} .^{40,41}$ The weak coupling is consistent with the spin being localized on the nickel center.

\section{Electronic Structure Analysis}

The geometries of the various species were optimized using DFT/BP86 and compared to the available experimental data to further probe the electronic structures of $[\mathbf{1 a}-\mathbf{1 d}]^{+}$and $[\mathbf{1 a}-$ 1d $]^{0}$. The optimized geometries are in good agreement with the $X$-ray crystal structures. Relevant bond lengths for $[\mathbf{1 a}]^{+}$and $[\mathbf{1 a}]^{0}$ are compared in Table 5. The $\mathrm{BF}_{4}{ }^{-}$counterions were not included in the geometry optimizations, which may introduce minor discrepancies between the X-ray crystal and DFT-optimized structures. Comparisons between the DFT and X-ray crystal structures for species $[\mathbf{1 b}-\mathbf{1 d}]^{+}$and $[\mathbf{2 b}]^{0}$, as well as structural and energetic information for all systems studied, are provided in Tables S4-S8. Moreover, the CO stretching frequencies $\left(v_{\mathrm{CO}}\right)$ calculated with DFT are also in good agreement with the experimental data (Tables 2 and 4$)$.

The short Ni-Fe distances in both $[\mathbf{1 a}]^{+}$and $[\mathbf{1 a}]^{0}$ suggest the presence of metal-metal bonding interactions. According to previous analyses, such $\mathrm{Ni}-\mathrm{Fe}$ bonds typically arise from overlap of the $d_{z^{2}}$ orbitals. ${ }^{21,42,43}$ Interestingly, however, the nature of the $\mathrm{Ni}-\mathrm{Fe}$ bonding is quite different between $[\mathbf{1 a}]^{+}$and $[\mathbf{1 a}]^{0}$, as revealed by analysis of the bonding molecular orbitals (MOs) localized using the Pipek-Mezey criteria. ${ }^{44}$ For $[\mathbf{1 a}]^{+}$, the bonding orbital (Figure 9, left) reveals a dative $\mathrm{Ni} \rightarrow \mathrm{Fe}$ two-center, two-electron bond, which resembles a Lewis acid-base-type interaction between the $\mathrm{d}^{8} \mathrm{Ni}^{\mathrm{II}}$ and $\mathrm{d}^{6} \mathrm{Fe}^{\mathrm{II}}$ centers. In contrast, for $[\mathbf{1 a}]^{0}$, a more covalent two-center, two-electron bond is present (Figure 9, right), in which the $\mathrm{Ni}$ and $\mathrm{Fe}_{z^{2}}$ orbitals contribute equally to the bonding orbital. An alternative bonding analysis using natural bond orbitals (NBOs) ${ }^{45}$ is provided in the Supporting Information (pp $\mathrm{S} 38-\mathrm{S} 40$ ). The formation of a stronger $\sigma$ bond in $[\mathbf{1 a}]^{0}$ is consistent with the experimentally observed contraction of the Ni-Fe bond distance from $2.51 \AA$ in $[\mathbf{1 a}]^{+}$to $2.46 \AA$ in [1a] $]^{0}$. This Ni-Fe bond-length contraction is also found in the DFT-optimized structures (Table 5). These chemical bonding patterns are similar for $[\mathbf{2 b}]^{+}$and $[\mathbf{2 b}]^{0}$ (Figure S58), indicating that the stereochemistry at iron and the presence of $\mathrm{SPh}^{-}$or $\mathrm{R}_{2} \mathrm{pdt}^{2-}$ does not disrupt the $\mathrm{Ni}-\mathrm{Fe}$ bond.

\section{Protonation of Ni-L Model}

Upon treatment with $\geq 1$ equiv of acid, solutions of $[\mathbf{1 a}]^{0}$ liberate $\mathrm{H}_{2}$ and afford the formation of $[\mathbf{1 a}]^{+}$(eq 4). 


$$
\left.\left.\left.\left[\left(\mathrm{C}_{5} \mathrm{H}_{5}\right) \mathrm{Ni}(\mathrm{pdt}) \mathrm{Fe}(\mathrm{CO})(\mathrm{dppe})\right]+\mathrm{H}^{+} \rightarrow \underset{[\mathbf{1}]^{0}}{\left[\mathrm{la}^{+}\right.}\right]^{+} \mathrm{C}_{5} \mathrm{H}_{5}\right) \mathrm{Ni}(\mathrm{pdt}) \mathrm{Fe}(\mathrm{CO})(\text { dppe })\right]^{+}+\frac{1}{2} \mathrm{H}_{2}
$$

$\mathrm{H}_{2}$ evolution was observed for $\mathrm{HBF}_{4}$, $p$-toluenesulfonic acid $\left(\mathrm{p} K_{\mathrm{a}}{ }_{\mathrm{aeCN}}=8.01\right)$, and [pyridinium] $\mathrm{BF}_{4}\left(\mathrm{p} K_{\mathrm{a}}{ }^{\mathrm{MeCN}}=12.33\right)$ but not for $\left[\mathrm{NH}_{4}\right] \mathrm{PF}_{6}\left(\mathrm{p} K_{\mathrm{a}}{ }^{\mathrm{MeCN}}=14.46\right)$. With $\mathrm{HBF}_{4}$, the yield of $\mathrm{H}_{2}$ was 0.44 equiv, as assayed by gas chromatography. With $[\mathbf{1 a}]^{0}$ functioning as a one-electron reductant, 0.5 equiv would be predicted.

Protonolysis of [1a] ${ }^{0}$ to give $[\mathbf{1 a}]^{+}$entails the conversion of an $S=1 / 2$ precursor to an $S=0$ product, which implicates a multistep process involving electron transfer. We anticipated that protonation of $[\mathbf{1 a}]^{0}$ would afford $\left[\left(\mathrm{C}_{5} \mathrm{H}_{5}\right) \mathrm{Ni}(\mathrm{pdt}) \mathrm{HFe}-(\mathrm{CO})(\mathrm{dppe})\right]^{+}\left([\mathrm{H1} \mathbf{a}]^{+}\right), \mathrm{a} \mathrm{Ni}^{\mathrm{III}}$ $\mathrm{Fe}^{\mathrm{II}}$ species (see the DFT section below). However, hydrides were not obtained experimentally; rather, only [1a $]^{+}$was obtained. To explain this result, $[\mathrm{H1} \mathbf{a}]^{+}$is proposed to undergo reduction by its conjugate base $[\mathbf{1 a}]^{0}$, giving $[\mathrm{H1} \mathbf{1 a}]^{0}$, which, in turn, undergoes protonolysis to give $[\mathbf{1 a}]^{+}$. Similarly, we found that protonation of $[\mathbf{2 b}]^{0}$ afforded $[\mathbf{2 b}]^{+}$. The proposed sequence of reactions is summarized in Scheme 1.

\section{Proposed $\mathrm{H}_{2}$ Evolution Mechanism}

In the presence of excess acid, [1a $]^{0 /+}$ is a formal, albeit slow, electrocatalyst for $\mathrm{H}_{2}$ evolution. Using trifluoroacetic acid, the catalytic current is observed at $-1.16 \mathrm{~V}$, corresponding to the [1a] ${ }^{+/ 0}$ couple, with an acid-independent rate ${ }^{46}$ of ca. $4 \mathrm{~s}^{-1}$ (Figure S32). Because the hydride intermediates could not be characterized, they were analyzed with DFT in the context of the mechanism for $\mathrm{H}_{2}$ evolution. Additionally, the exclusive observation of the dibasal intermediate prompted theoretical investigation of an apical-basal isomer. These calculations provide insight into the structure and bonding of the nickel(III) hydride intermediate and also predict the occurrence of two parallel catalytic cycles involving isomers of $[\mathbf{1 a}]^{0}$. Similar bimetallic hydrides have been known to adopt different isomers. ${ }^{22,47}$ Furthermore, recent work suggests that the protonation of (dppe)Ni(pdt)$\mathrm{Fe}(\mathrm{CO})_{3}$ proceeds via an unobserved isomer. ${ }^{21}$

According to the calculations, the dibasal and apical-basal isomers of $[\mathbf{1 a}]^{0}$ are nearly isoergic $\left(\Delta G^{\circ}=+0.48 \mathrm{kcal} \mathrm{mol}^{-1}\right)$ and interconvert via a relatively low free energy barrier, $\Delta G^{\ddagger}=11.76 \mathrm{kcal} \mathrm{mol}^{-1}$ (Table 11); however, all other protonation and oxidation states have a much higher barrier for isomerization $\left(\Delta G>20 \mathrm{kcal} \mathrm{mol}^{-1}\right)$. This result prompted the investigation of two parallel pathways for $\mathrm{H}_{2}$ evolution, labeled A and B in Figure 10.

These pathways are initiated by protonation of isomers of $[\mathbf{1 a}]^{0}$ that differ in terms of the stereochemistry of the (pdt)Fe(dppe)(CO) site. The adoption of the apical-basal isomer does not disrupt the Ni-Fe $\sigma$ bond (Figure S56) or the localization of the unpaired spin density (Table 10 and Figure S57). The isomerization from the dibasal to the apical-basal configuration is expected to occur only for the $[\mathbf{1 a}]^{0}$ species because the calculated $\Delta G^{\neq}$ values for the analogous isomerization for all other intermediates in the catalytic cycle shown in Figure 10 are greater than $20 \mathrm{kcal} \mathrm{mol}^{-1}$ (Table 11). DFT analysis revealed that the transition state (TS) for this isomerization disrupts the metal-metal bonding (Supporting Information, p S41). For $[\mathbf{1 a}]^{0}$, the TS is best described as $\mathrm{Ni}^{\mathrm{II}} \mathrm{Fe}^{\mathrm{I}}$, while the $\mathrm{TS}$ is $\mathrm{Ni}^{\mathrm{II}} \mathrm{Fe}^{\mathrm{II}}$ in 
$[\mathbf{1 a}]^{+}$. The lower isomerization barrier for $[\mathbf{1 a}]^{0}$ is attributed to the greater stability of fivecoordinated $\mathrm{Fe}^{\mathrm{I}}$ compared to five-coordinated $\mathrm{Fe}^{\mathrm{II}}$.

The first step in the catalytic cycle produces isomers of [H1a $]^{+}$. In both isomers, the unpaired electron is localized mainly in the nickel coordination sphere (Table 10), indicating that these species are best described as $\mathrm{Ni}^{\mathrm{III}} \mathrm{HFe}^{\mathrm{II}}$, analogous to the $\mathrm{Ni}-\mathrm{C}$ state in the enzyme. Moreover, the DFT-optimized structure of $[\mathrm{H1a}]^{+}$reveals that the hydride is more closely bound to iron than to nickel.

Subsequent to its formation, $[\mathrm{H1} \mathbf{1 a}]^{+}$is reduced by a second 1 equiv of $[\mathbf{1 a}]^{0}$ to form $[\mathbf{1 a}]^{+}$ and the nickel(II)-iron(II) hydride [H1a] $]^{0}$. This electron transfer is proposed to occur spontaneously on the basis of the calculated reduction potential of $[\mathrm{H1} \mathbf{1}]^{+}$, which is less negative than the calculated reduction potential of [1a $]^{+}$by 0.16 (cycle $\mathrm{A}$ ) and $0.03 \mathrm{~V}$ (cycle B) versus $\mathrm{Fc}^{+/ 0}$ in $\mathrm{CH}_{2} \mathrm{Cl}_{2}$. Reduction to form [H1a] ${ }^{0}$ mainly affects the nickel center and results in significant elongation of the $\mathrm{Ni}-\mathrm{H}$ distance by 0.64 and $0.26 \AA$ for the $\mathrm{A}$ and $\mathrm{B}$ isomers, respectively. Thus, $[\mathrm{H1a}]^{0}$, which would be analogous to the Ni-R state of the enzyme, is more accurately described as a semiterminal iron(II) hydride than a bridging hydride.

The catalytic cycle closes with the protonation of [H1a $]^{0}$ to produce the $\mathrm{H}_{2}$-adduct intermediate, $\left[\mathrm{H}_{2} \mathbf{1 a}\right]^{+}$, followed by the release of $\mathrm{H}_{2}$ from $\left[\mathrm{H}_{2} \mathbf{1 a}\right]^{+}$to generate $[\mathbf{1 a}]^{+}$. Although the two cycles are very similar energetically, the calculations predict that this protonation is thermodynamically less favorable for the apical-basal isomer $\left[\mathrm{H1a}^{\mathbf{B}}\right]^{0}$ than for the dibasal isomer $\left[\mathrm{H1a}^{\mathrm{A}}\right]^{0}$ by $\sim 5 \mathrm{kcal} \mathrm{mol}^{-1}$.

In light of these computational results, additional experiments were performed to probe for the presence of two isomers in the catalytic cycle. The calculated $v_{\mathrm{CO}}$ values for $\left[\mathbf{1 a}^{\mathbf{A}}\right]^{0}$ and $\left[\mathbf{1 a}^{\mathbf{B}}\right]^{0}$ are 1901 and $1904 \mathrm{~cm}^{-1}$, respectively, and the calculated $v_{\mathrm{CO}}$ values for $\left[\mathbf{1 a}^{\mathbf{A}}\right]^{+}$and $\left[\mathbf{1 a}^{\mathbf{B}}\right]^{+}$are 1946 and $1949 \mathrm{~cm}^{-1}$, respectively. The calculated $v_{\mathrm{CO}}$ values for all intermediates in the catalytic cycles are provided in Table S11. These small calculated $v_{\mathrm{CO}}$ differences between the isomers are within the numerical accuracy of DFT. As previously mentioned, solutions of $[\mathbf{1 a}]^{+}$, which were synthesized directly, were confirmed crystallographically and spectroscopically to exist only in the dibasal geometry. However, the preparation of $[\mathbf{1 a}]^{+}$by the addition of excess acid to $[\mathbf{1 a}]^{0}$, presumably going through the catalytic cycle(s) to generate $\mathrm{H}_{2}$, produced a solution containing both isomers of [1a] $]^{+}$. The ${ }^{31} \mathrm{P}$ NMR spectrum of the $[\mathbf{1 a}]^{+}$solution obtained after presumably proceeding through the catalytic cycle(s) displayed two ${ }^{31} \mathrm{P}$ NMR signals, one assigned to the dibasal isomer (cycle $\mathrm{A}$ ), in which the two ${ }^{31} \mathrm{P}$ centers are equivalent, and the other assigned to the apicalbasal isomer (cycle $\mathrm{B}$ ), in which the two ${ }^{31} \mathrm{P}$ centers are equilibrated by the rocking motion shown in Figure 11. The free energy barrier to this rocking motion is calculated to be relatively low, $\Delta G^{\ddagger}=9.5 \mathrm{kcal} \mathrm{mol}^{-1}$, and the ${ }^{31} \mathrm{P} \mathrm{NMR}$ spectrum of the isomer mixture was unchanged when recorded at $-100{ }^{\circ} \mathrm{C}$, consistent with a relatively low free energy barrier. These analyses support the proposal that $\mathrm{H}_{2}$ evolution can proceed via either cycle $\mathrm{A}$ or cycle B shown in Figure 10, thereby producing both isomers of $[\mathbf{1 a}]^{+}$. 


\section{CONCLUSIONS}

Experiment and theory indicate that the new complexes reported in this paper replicate aspects of the following enzyme states: Ni-SI $, \mathrm{Ni}-\mathrm{L}, \mathrm{Ni}-\mathrm{C}$, and Ni-R. Two of these species, the $\mathrm{Ni}^{\mathrm{II}} \mathrm{Fe}^{\mathrm{II}}$ and $\mathrm{Ni}^{\mathrm{I}} \mathrm{Fe}^{\mathrm{II}}$ derivatives, were crystallized and fully characterized. The other two species are implicated in a $\mathrm{H}_{2}$ evolution experiment and characterized computationally.

The Ni-SI state is distinguished by the $\mathrm{Ni}^{\mathrm{II}} \mathrm{Fe}^{\mathrm{II}}$ bimetallic core and the absence of a third bridging ligand, features that are replicated in compounds $[\mathbf{1 a}-\mathbf{1 d}] \mathrm{BF}_{4}$. The Ni-L state is distinguished by the formal $\mathrm{Ni}^{\mathrm{I}} \mathrm{Fe}^{\mathrm{II}}$ oxidation states, a feature that is replicated in $[\mathbf{1 a}-\mathbf{1 d}]^{0}$. The oxidation state assignments are supported by EPR and Mössbauer spectroscopic data, crystallographic results, voltammetric measurements, and DFT calculations.

The previous attempts to model states with $\mathrm{Ni}^{\mathrm{II}} \mathrm{Fe} \mathrm{II}^{\mathrm{II}}$ cores suffered from the presence of sixcoordinated iron centers. ${ }^{17,48}$ The $\mathrm{Ni}^{\mathrm{II}} \mathrm{Fe}^{\mathrm{II}}$ models reported in this paper, in fact, arise via such $\mathrm{FeL}_{4}(\mu \text {-SR })_{2}$-containing intermediates, which undergo decarbonylation. DFT analysis of the bonding suggests that decarbonylation is driven by formation of the Ni-Fe bond.

Although $[\mathbf{1 a}-\mathbf{1 d}]^{+}$and $[\mathbf{2} \mathbf{b}]^{+}$are reasonable spectroscopic models for the $\mathrm{Ni}_{-} \mathrm{SI}_{\mathrm{a}}$ state of the enzyme, challenges remain. In the $\mathrm{Ni}_{-} \mathrm{SI}_{\mathrm{a}}$ state, the nickel center binds $\mathrm{CO}$ to give Ni$\mathrm{SI}_{\mathrm{a}}{ }^{\mathrm{CO} .6,49}$ In contrast, $[\mathbf{1 a}-\mathbf{1 d}]^{+}$exhibit no detectable affinity for CO. Substitution of the dithiolate bridge with bridging monothiolates, as in $[\mathbf{2 b}]^{+}$, facilitates the binding of $\mathrm{CO}$ at iron. In contrast, the enzyme binds $\mathrm{CO}$ at nickel. This difference is understandable because the $\left(\mathrm{C}_{5} \mathrm{H}_{5}\right) \mathrm{Ni}(\mu-\mathrm{SR})_{2}$ site has a higher electron count than the $(\mathrm{RS})_{2} \mathrm{Ni}(\mu-\mathrm{SR})_{2}$ site found in the enzyme. Replicating terminal thiolate ligation at nickel remains one of the central challenges in this area. ${ }^{50}$

The first attempts to model the mixed-valence active site of the Ni-L state focused on $\left[(\mathrm{CO})_{2} \mathrm{LFe} \text { (pdt) Ni-(diphosphine) }\right]^{+.20,28}$ These cations are described as $\mathrm{Ni}^{\mathrm{II}} \mathrm{Fe}^{\mathrm{I}}$, which is reversed from the $\mathrm{Ni}^{\mathrm{I}} \mathrm{Fe}^{\mathrm{II}}$ states assigned in $\mathrm{Ni}-\mathrm{L}$. More recently, we have characterized complexes with the configuration $\mathrm{Ni}^{\mathrm{I}} \mathrm{Ru}^{\mathrm{II}}$, wherein the $\mathrm{Ru}^{\mathrm{II}}$ center is redox-inactive. ${ }^{51} \mathrm{In}$ this work, the $\mathrm{Fe}(\mathrm{CO})_{2}\left(\mathrm{PR}_{3}\right)$ center in previous $\mathrm{Fe}-\mathrm{Ni}$ models was replaced by a $\mathrm{Fe}(\mathrm{CO})$ $\left(\mathrm{PR}_{3}\right)_{2}$ center, which stabilizes the $\mathrm{Fe}^{\mathrm{II}}$ state, as illustrated by $[\mathbf{1 a}-\mathbf{1 d}]^{0}$ and $[\mathbf{2 b}]^{0}$.

Because they are substrates, hydrogenic ligands are a major focus in research concerning the hydrogenases and their models. ${ }^{52,53}$ The DFT-optimized analysis of the nickel(III)-iron(II) hydride $[\mathrm{H1a}]^{+}$reveals that the unpaired electron is localized mainly in the nickel coordination sphere, as seen for Ni-C. In the model, the hydride ligand is more closely bound to iron than to nickel $[\Delta(\mathrm{M}-\mathrm{H}) \sim 0.2 \AA]$. This report is the first suggestion of the accessibility of such a state in [NiFe]-hydrogenase model complexes. In the enzyme, protontransfer reactions are coupled to electron-transfer reactions, ${ }^{16}$ and a similar effect is seen in the reduction of $[\mathrm{H1a}]^{+}$by $[\mathbf{1 a}]^{0}$. The resulting nickel(II)-iron(II) hydride [H1a $]^{0}$, analogous to the Ni-R state of the enzyme, reacts with proton sources to liberate $\mathrm{H}_{2}$. Although thwarting efforts to isolate this hydride, this facile protonolysis is analogous to the behavior of the Ni-R/Ni-SI pair. ${ }^{16}$ According to our calculations, the nickel(II)-iron(II) hydride is more accurately described as a terminal iron(II) hydride than a bridging hydride. In contrast, high-resolution X-ray crystallographic analysis of Ni-R from D. vulgaris reveals $\mathrm{Ni}-\mathrm{H}$ and 
Fe-H distances of 1.58 and $1.78 \AA$ (error $0.08 \AA$ ), respectively; i.e., the hydride is more closely associated with nickel. ${ }^{16}$ The structural difference between the model complex and the protein may reflect the influence of terminal thiolate ligands on nickel..$^{50}$

\section{EXPERIMENTAL SECTION}

Reactions and manipulations were performed using standard Schlenk techniques at room temperature or in a nitrogen atmosphere glovebox. Solvents were HPLC-grade and dried by filtration through activated alumina or distilled under nitrogen over an appropriate drying agent. $\mathrm{Bu}_{4} \mathrm{NPF}_{6}(\mathrm{GFS}$ Chemicals, Columbus, $\mathrm{OH}$ ) was recrystallized multiple times from a $\mathrm{CH}_{2} \mathrm{Cl}_{2}$ solution by the addition of hexane. Chromatography was performed using Siliflash P60 from Silicycle (230-400 mesh). ESI-MS data for compounds were acquired using a Waters Micromass Quattro II spectrometer. ${ }^{1} \mathrm{H}$ NMR spectra $(500 \mathrm{MHz})$ were referenced to residual solvent relative to tetramethylsilane. ${ }^{31} \mathrm{P}\left\{{ }^{1} \mathrm{H}\right\}$ NMR spectra $(202 \mathrm{MHz})$ were referenced to external $85 \% \mathrm{H}_{3} \mathrm{PO}_{4}$. Fourier transform infrared (FT-IR) spectra were recorded on a PerkinElmer 100 FT-IR spectrometer. Crystallographic data for compounds $[\mathbf{1 a}]^{0},[\mathbf{1}]^{0},[\mathbf{2 b}]^{0}$, and $[\mathbf{2 b}] \mathrm{BF}_{4}$ were collected using a Siemens SMART diffractometer equipped with a Mo Ka source $(\lambda=0.71073 \AA)$, and crystallographic data for compounds [1a] $\mathrm{BF}_{4}$ and $[\mathbf{1 d}] \mathrm{BF}_{4}$ were collected using a Bruker D8 Venture diffractometer equipped with a Mo Ka microfocus source and a Photon 100 detector. X-band EPR spectra were recorded on a Varian E-line 12" Century Series X-band continuous-wave spectrometer. Qband ENDOR spectra were recorded on a Bruker Elexsys E580 Q-band pulse EPR spectrometer using a home-built pulse Q-band ENDOR resonator ${ }^{54}$ and an ENI 300L RF amplifier. Cryogenic temperatures were achieved using a Cryogenic Ltd. closed-cycle cryostat. ENDOR simulations and spectral fits were performed using EasySpin ("salt") ${ }^{55}$ and home-written scripts in Matlab. Mössbauer spectra were recorded on an alternating constant-acceleration spectrometer. The minimum experimental line width was $0.24 \mathrm{~mm} \mathrm{~s}^{-1}$ (full width at half-maximum). The sample temperature was maintained constant in either an Oxford Variox or an Oxford Mössbauer-Spectromag cryostat. The latter is a split-pair conducting magnet system for applying fields of up to $8 \mathrm{~T}$ to the samples that can be kept at temperatures in the range $1.5-250 \mathrm{~K}$. The field at the sample is perpendicular to the $\gamma$-ray beam. Isomer shifts are quoted relative to metallic iron at $300 \mathrm{~K}$. Mössbauer spectra were simulated with a home-written spin-Hamiltonian program based on the usual nuclear Hamiltonian formalism. ${ }^{37}$

\section{$\left[\left(\mathrm{C}_{5} \mathrm{H}_{5}\right)_{3} \mathrm{Ni}_{2}\right] \mathrm{BF}_{4},\left[\left(\mathrm{MeC}_{5} \mathrm{H}_{4}\right)_{3} \mathrm{Ni}_{2}\right] \mathrm{BF}_{4}$, and $\left[\left(\mathrm{C}_{5} \mathrm{D}_{5}\right)_{3} \mathrm{Ni}_{2}\right] \mathrm{BF}$}

In a modification of Werner's procedure, ${ }^{56}$ a solution of nickelocene $(2.08 \mathrm{~g}, 11.0 \mathrm{mmol})$ in $\mathrm{Et}_{2} \mathrm{O}(150 \mathrm{~mL})$ was treated dropwise with an excess of $\mathrm{HBF}_{4} \cdot \mathrm{Et}_{2} \mathrm{O}(2 \mathrm{~mL}, 13.8 \mathrm{~mol})$. Over the course of several minutes, a purple solid precipitated from a pale yellow solution. The solid was collected by filtration and washed thoroughly with ether. Yield: $2.07 \mathrm{~g}(95 \%) .{ }^{1} \mathrm{H}$ NMR (nitromethane- $\left.d_{3}\right): \delta 5.48(10 \mathrm{H}, \mathrm{s}), 4.80(5 \mathrm{H}, \mathrm{s}) .{ }^{13} \mathrm{C}\left\{{ }^{1} \mathrm{H}\right\}$ NMR (nitromethane- $\left.d_{3}\right): \delta$ 87.8, 56.6. 


\section{$\left[\left(\mathrm{C}_{5} \mathrm{H}_{5}\right) \mathrm{Ni}(\mathrm{pdt}) \mathrm{Fe}(\mathrm{dppe})(\mathrm{CO}) \mathrm{BF}_{4}\left(\left[\mathrm{a}_{\mathrm{aBF}}\right)\right.\right.$}

To a solution of $\left[\left(\mathrm{C}_{5} \mathrm{H}_{5}\right)_{3} \mathrm{Ni}_{2}\right] \mathrm{BF}_{4}(498 \mathrm{mg}, 1.24 \mathrm{mmol})$ in $\mathrm{CH}_{3} \mathrm{NO}_{2}(50 \mathrm{~mL})$ was added a solution of $\mathrm{Fe}$ (pdt)(dppe)(CO) ${ }_{2}^{22}(771 \mathrm{mg}, 1.25 \mathrm{mmol})$ in $\mathrm{CH}_{3} \mathrm{NO}_{2}(25 \mathrm{~mL})$. After $30 \mathrm{~min}$, the slurry converted to a dark-red solution. Solvent was removed under reduced pressure, and the residue was washed several times with pentane until the filtrate was colorless. The residue was extracted into a minimal volume of $\mathrm{CH}_{2} \mathrm{Cl}_{2}$ and subjected to column chromatography. Byproducts elute with $100 \% \mathrm{CH}_{2} \mathrm{Cl}_{2}$. The product eluted with 90:10 $\mathrm{CH}_{2} \mathrm{Cl}_{2} / \mathrm{THF}$ as a dark-red band. The solvent was removed under reduced pressure to yield a dark-red solid. Yield: $841 \mathrm{mg}(85 \%) .{ }^{1} \mathrm{H}$ NMR (acetone- $\left.d_{6}\right): 8.01(\mathrm{~m}, 4 \mathrm{H}), 7.5(\mathrm{~m}, 16 \mathrm{H})$, $4.75\left(\mathrm{~s}, 5 \mathrm{H}, \mathrm{C}_{5} \mathrm{H}_{5}\right), 3.83\left(\mathrm{~m}, 2 \mathrm{H}, \mathrm{PCH}_{2} \mathrm{CH}_{2} \mathrm{P}\right), 3.62\left(\mathrm{~m}, 2 \mathrm{H}, \mathrm{PCH}_{2} \mathrm{CH}_{2} \mathrm{P}\right), 2.83(\mathrm{~m}, 3 \mathrm{H}), 2.43$ $(\mathrm{m}, 2 \mathrm{H}), 1.66\left(\mathrm{~m}, 1 \mathrm{H}, \mathrm{S}_{2} \mathrm{CH}_{2} \mathrm{CH}_{2} \mathrm{CH}_{2} \mathrm{~S}_{2}\right) .{ }^{31} \mathrm{P}\left\{{ }^{1} \mathrm{H}\right\}$ NMR (acetone- $\left.d_{6}\right): \delta 77.1$. ESI-MS: $\mathrm{m} / \mathrm{z}$ $711\left([\mathrm{M}]^{+}\right), 683\left([\mathrm{M}-\mathrm{CO}]^{+}\right)$. IR $\left(\mathrm{CH}_{2} \mathrm{Cl}_{2}\right): v_{\mathrm{CO}} 1943 \mathrm{~cm}^{-1}$ (THF). Anal. Calcd for $\mathrm{C}_{35} \mathrm{H}_{35} \mathrm{FeNiOP}_{2} \mathrm{~S}_{2}$ (found): C, 52.61 (52.67); H, 4.42 (4.70). Single crystals of [1a] $\mathrm{BF}_{4}$ were obtained by vapor diffusion of pentane into THF solutions.

\section{$\left[\left(\mathrm{C}_{5} \mathrm{H}_{5}\right) \mathrm{Ni}(\mathrm{pdt}) \mathrm{Fe}(\mathrm{dppv})(\mathrm{CO}) \mathrm{BF}_{4}\left(\left[\mathrm{1b}_{\mathrm{B}} \mathrm{BF}_{4}\right)\right.\right.$}

Compound [1b] $\mathrm{BF}_{4}$ was prepared in a fashion similar to that of $[\mathbf{1 a}] \mathrm{BF}_{4}$ using $\mathrm{Fe}(\mathrm{pdt})$ $(\mathrm{dppv})(\mathrm{CO})_{2}{ }^{22}$ as the iron reagent. Yield: $66 \%$, dark-red powder. ${ }^{1} \mathrm{H} \mathrm{NMR}\left(\mathrm{CH}_{2} \mathrm{Cl}_{2}\right): \delta 8.44$ (m, 2H, PCHCHP), 7.91 (br, 4H), 7.54 (s, br, 4H), 7.45 (s, br 12H), 4.31 (s, 5H, $\mathrm{C}_{5} H_{5}$ ), 2.77 $(\mathrm{m}, 3 \mathrm{H}) 2.36(\mathrm{~m}, 2 \mathrm{H}), 1.69\left(\mathrm{~m}, 1 \mathrm{H}, \mathrm{S}_{2} \mathrm{CH}_{2} \mathrm{CH}_{2} \mathrm{CH}_{2} \mathrm{~S}_{2}\right) .{ }^{31} \mathrm{P}\left\{{ }^{1} \mathrm{H}\right\} \mathrm{NMR}\left(\mathrm{CH}_{2} \mathrm{Cl}_{2}\right): \delta 83.8$. ESI-MS: $m / z 709\left([\mathrm{M}]^{+}\right), 681\left(\left[\mathrm{M}-\mathrm{CO}^{+}\right)\right.$. IR $\left(\mathrm{CH}_{2} \mathrm{Cl}_{2}\right): \tilde{v_{\mathrm{CO}}} 1951 \mathrm{~cm}^{-1}$.

\section{$\left[\left(\mathrm{C}_{5} \mathrm{H}_{5}\right) \mathrm{Ni}\left(\mathrm{Me}_{2} \mathrm{pdt}\right) \mathrm{Fe}(\mathrm{dppe})(\mathrm{CO}) \mathrm{BF}_{4}\left([1 \mathrm{c}] \mathrm{BF}_{4}\right)\right.$}

Compound $[\mathbf{1 c}] \mathrm{BF}_{4}$ was prepared in a fashion similar to that of [1a] $\mathrm{BF}_{4}$ using $\mathrm{Fe}\left(\mathrm{Me}_{2} \mathrm{pdt}\right)$ (dppe) $(\mathrm{CO})_{2}{ }^{22}$ as the iron source. Yield: $77 \%$, dark-red powder. ${ }^{1} \mathrm{H}$ NMR $\left(\mathrm{CH}_{2} \mathrm{Cl}_{2}\right): \delta 7.77$ (m, 4H), 7.46 (m, 16), 4.46 (s, 5H, $\mathrm{C}_{5} \mathrm{H}_{5}$ ), $3.65\left(\mathrm{~m}, 2 \mathrm{H}, \mathrm{PCH}_{2} \mathrm{CH}_{2} \mathrm{P}\right), 3.11(\mathrm{~m}, 2 \mathrm{H}$ $\left.\mathrm{PCH}_{2} \mathrm{CH}_{2} \mathrm{P}\right), 2.71\left(\mathrm{~m}, 2 \mathrm{H}, \mathrm{S}_{2} \mathrm{CH}_{2} \mathrm{CMe}_{2} \mathrm{CH}_{2} \mathrm{~S}_{2}\right), 2.17\left(\mathrm{~m}, 2 \mathrm{H}, \mathrm{S}_{2} \mathrm{CH}_{2} \mathrm{CMe}_{2} \mathrm{CH}_{2} \mathrm{~S}_{2}\right), 1.50$ (s, $\left.3 \mathrm{H}, \mathrm{S}_{2} \mathrm{CH}_{2} \mathrm{CMe}_{2} \mathrm{CH}_{2} \mathrm{~S}_{2}\right), 1.19\left(\mathrm{~s}, \mathrm{~S}_{2} \mathrm{CH}_{2} \mathrm{CMe}_{2} \mathrm{CH}_{2} \mathrm{~S}_{2}\right) \cdot{ }^{31} \mathrm{P}\left\{{ }^{1} \mathrm{H}\right\} \mathrm{NMR}\left(\mathrm{CD}_{2} \mathrm{Cl}_{2}\right): \delta 75.1$. ESI-MS: $m / z 739\left([\mathrm{M}]^{+}\right), 711\left([\mathrm{M}-\mathrm{CO}]^{+}\right)$. IR $\left(\mathrm{CH}_{2} \mathrm{Cl}_{2}\right): v_{\mathrm{CO}} 1940 \mathrm{~cm}^{-1}$. Single crystals of $[\mathbf{1 c}] \mathrm{BF}_{4}$ were obtained by evaporation of concentrated THF solutions.

\section{$\left[\left(\mathrm{CH}_{3} \mathrm{C}_{5} \mathrm{H}_{4}\right) \mathrm{Ni}(\mathrm{pdt}) \mathrm{Fe}(\mathrm{dppe})(\mathrm{CO})\right] \mathrm{BF}_{4}\left([1 \mathrm{~d}] \mathrm{BF}_{4}\right)$}

Compound $[\mathbf{1 d}] \mathrm{BF}_{4}$ was prepared in a similar fashion to $[\mathbf{1 a}] \mathrm{BF}_{4}$ using the $\left[\left(\mathrm{CH}_{3} \mathrm{C}_{5} \mathrm{H}_{4}\right)_{3} \mathrm{Ni}_{2}\right] \mathrm{BF}_{4}$ as the nickel source and $\mathrm{Fe}(\mathrm{pdt})(\mathrm{dppe})(\mathrm{CO})_{2}$ as the iron source. Yield: 81\%, dark-red powder. ${ }^{1} \mathrm{H}$ NMR $\left(\mathrm{CH}_{2} \mathrm{Cl}_{2}\right): \delta 7.80(\mathrm{br}, 4 \mathrm{H}) 7.52(\mathrm{br}, 4 \mathrm{H}) 7.43(\mathrm{br}, 12 \mathrm{H}), 4.67$ (br, 1H) 3.91 (br, 1H), $3.82(\mathrm{~s}, 3 \mathrm{H}), 3.43\left(\mathrm{~m}, 2 \mathrm{H}, \mathrm{PCH}_{2} \mathrm{CH}_{2} \mathrm{P}\right), 3.05\left(\mathrm{~m}, 2 \mathrm{H}, \mathrm{PCH}_{2} \mathrm{CH}_{2} \mathrm{P}\right)$, $3.05(\mathrm{~m}, 3 \mathrm{H}), 2.31(\mathrm{~m}, 2 \mathrm{H}), 1.89(\mathrm{br}, 2 \mathrm{H}), 1.75\left(\mathrm{~m}, 1 \mathrm{H}, \mathrm{S}_{2} \mathrm{CH}_{2} \mathrm{CH}_{2} \mathrm{CH}_{2} \mathrm{~S}_{2}\right) .{ }^{31} \mathrm{P}\left\{{ }^{1} \mathrm{H}\right\} \mathrm{NMR}$ $\left(\mathrm{CD}_{2} \mathrm{Cl}_{2}\right): \delta 79.2$. ESI-MS: $m / z 725\left([\mathrm{M}]^{+}\right), 697\left([\mathrm{M}-\mathrm{CO}]^{+}\right)$. IR $\left(\mathrm{CH}_{2} \mathrm{Cl}_{2}\right): \tilde{v_{\mathrm{CO}}} 1943 \mathrm{~cm}^{-1}$.

\section{$\left[\left(\mathrm{C}_{5} \mathrm{D}_{5}\right) \mathrm{Ni}(\mathrm{pdt}) \mathrm{Fe}(\mathrm{dppe})(\mathrm{CO})\right] \mathrm{BF}_{4}\left([1 \mathrm{a}] \mathrm{BF}_{4}-d_{5}\right)$}

Compound [1a] $\mathrm{BF}_{4}-d_{5}$ was prepared in a fashion similar to that of [1a] $\mathrm{BF}_{4}$ using $\left[\left(\mathrm{C}_{5} \mathrm{D}_{5}\right)_{3} \mathrm{Ni}_{2}\right] \mathrm{BF}_{4}$ as the nickel source. The product was characterized by ESI-MS, which indicated $>95 \%$ deuteration (see the Supporting Information). 


\section{$\mathrm{Fe}(\mathrm{SPh})_{2}(\mathrm{CO})_{2}(\mathrm{dppv})$}

This compound was synthesized in a fashion similar to that of the published procedure. ${ }^{57}$ To a mixture of $\mathrm{FeSO}_{4} \cdot 7 \mathrm{H}_{2} \mathrm{O}(1.112 \mathrm{~g}, 4.0 \mathrm{mmol})$ and dppv (1.584 g, $\left.4.0 \mathrm{mmol}\right)$ in $\mathrm{MeOH}(80$ $\mathrm{mL})$ was added dropwise a solution of $\mathrm{PhSNa}(1.056 \mathrm{~g}, 8.0 \mathrm{mmol})$ in $\mathrm{MeOH}(20 \mathrm{~mL})$ with stirring under the presence of $\mathrm{CO}$. After stirring for $6 \mathrm{~h}$ at room temperature, the solvent was removed under reduced pressure. The residue was extracted with $\mathrm{CH}_{2} \mathrm{Cl}_{2}(40 \mathrm{~mL})$. After filtration to remove $\mathrm{Na}_{2} \mathrm{SO}_{4}$, the extract was concentrated $(15 \mathrm{~mL})$ and diluted with hexane $(50 \mathrm{~mL})$. Cooling this mixture at $-20{ }^{\circ} \mathrm{C}$ for $12 \mathrm{~h}$ gave a red solid. Yield: $2.23 \mathrm{~g}(77 \%) .{ }^{1} \mathrm{H}$ NMR $\left(\mathrm{CD}_{2} \mathrm{Cl}_{2}\right): \delta 6.85-8.03(32 \mathrm{H}, \mathrm{m}) .{ }^{31} \mathrm{P}\left\{{ }^{1} \mathrm{H}\right\} \mathrm{NMR}\left(\mathrm{CD}_{2} \mathrm{Cl}_{2}\right): \delta 81.9(\mathrm{~d}, J=55 \mathrm{~Hz}), 61.1$ $(\mathrm{d}, J=55 \mathrm{~Hz})$. IR $\left(\mathrm{CH}_{2} \mathrm{Cl}_{2}\right): v_{\mathrm{CO}} 2023,1978 \mathrm{~cm}^{-1}$.

\section{$\left[\left(\mathrm{C}_{5} \mathrm{H}_{5}\right) \mathrm{Ni}(\mathrm{SPh})_{2} \mathrm{Fe}(\mathrm{dppv})(\mathrm{CO})_{2}\right] \mathrm{BF}_{4}\left(\left[2 \mathrm{bCO} \mathrm{BF}_{4}\right)\right.$}

To a solution of $\left[\left(\mathrm{C}_{5} \mathrm{H}_{5}\right)_{3} \mathrm{Ni}_{2}\right] \mathrm{BF}_{4}(200 \mathrm{mg}, 0.5 \mathrm{mmol})$ in $\mathrm{CH}_{3} \mathrm{NO}_{2}(15 \mathrm{~mL})$ was added a solution of $\mathrm{Fe}(\mathrm{SPh})_{2}(\mathrm{dppv})(\mathrm{CO})_{2}(364 \mathrm{mg}, 0.5 \mathrm{mmol})$ in $\mathrm{CH}_{3} \mathrm{NO}_{2}(10 \mathrm{~mL})$. After $30 \mathrm{~min}$, the slurry converted to a dark-red solution. Solvent was removed under reduced pressure, and the residue was washed with pentane until the filtrate was colorless. The residue was extracted into a minimal volume of $\mathrm{CH}_{2} \mathrm{Cl}_{2}$ and subjected to column chromatography. After eluting impurities with $100 \% \mathrm{CH}_{2} \mathrm{Cl}_{2}$, the product eluted with $90: 10 \mathrm{CH}_{2} \mathrm{Cl}_{2} / \mathrm{THF}$ as a darkred band. The solvent was removed under reduced pressure to yield a dark-red solid. Yield: $380 \mathrm{mg}(81 \%) .{ }^{1} \mathrm{H}$ NMR $\left(\mathrm{CD}_{2} \mathrm{Cl}_{2}\right): \delta 6.85-8.57(32 \mathrm{H}, \mathrm{m}), \delta 4.46(5 \mathrm{H}, \mathrm{s}) .{ }^{31} \mathrm{P}\left\{{ }^{1} \mathrm{H}\right\}$ NMR $\left(\mathrm{CD}_{2} \mathrm{Cl}_{2}\right): \delta 75.9(\mathrm{~d}, J=45 \mathrm{~Hz}), 64.2(\mathrm{~d}, J=45 \mathrm{~Hz})$. ESI-MS: $m / z 849\left([\mathrm{M}]^{+}\right), 821([\mathrm{M}-$ $\left.\mathrm{CO}]^{+}\right), 793\left([\mathrm{M}-2 \mathrm{CO}]^{+}\right)$. IR $\left(\mathrm{CH}_{2} \mathrm{Cl}_{2}\right): v_{\mathrm{CO}} 2042,2002 \mathrm{~cm}^{-1}$. Anal. Calcd for $\mathrm{C}_{45} \mathrm{H}_{37} \mathrm{BF}_{4} \mathrm{FeNiO}_{2} \mathrm{P}_{2} \mathrm{~S}_{2} \cdot \mathrm{CH}_{2} \mathrm{Cl}_{2}$ (found): $\mathrm{C}, 54.05$ (53.69); $\mathrm{H}, 3.85$ (3.72). Single crystals of [2bCO]BF 4 were obtained by solvent diffusion of pentane into $\mathrm{CH}_{2} \mathrm{Cl}_{2}$ solutions.

\section{$\left[\left(\mathrm{C}_{5} \mathrm{H}_{5}\right) \mathrm{Ni}(\mathrm{SPh})_{2} \mathrm{Fe}(\mathrm{dppv})(\mathrm{CO})\right] \mathrm{BF}_{4}\left(\left[2 \mathrm{~b}_{\mathrm{BBF}}\right)\right.$}

To a solution of [ $2 \mathbf{b C O}] \mathrm{BF}_{4}(280 \mathrm{mg}, 0.3 \mathrm{mmol})$ in $\mathrm{CH}_{2} \mathrm{Cl}_{2}(30 \mathrm{~mL})$ was added $\mathrm{Me}_{3} \mathrm{NO} \cdot 2 \mathrm{H}_{2} \mathrm{O}$ (34 mg, $0.3 \mathrm{mmol}$ ). After $1 \mathrm{~h}$, the solvent was removed under reduced pressure, and the residue was washed several times with pentane. The residue was extracted into a minimal volume of $\mathrm{CH}_{2} \mathrm{Cl}_{2}(5 \mathrm{~mL})$, pentane $(30 \mathrm{~mL})$ was added, and the mixture was cooled to $-20{ }^{\circ} \mathrm{C}$. The product was collected as a black powder. Yield: $200 \mathrm{mg}$ (74\%). ${ }^{31} \mathrm{P}\left\{{ }_{\sim}^{1} \mathrm{H}\right\}$ NMR $\left(\mathrm{CD}_{2} \mathrm{Cl}_{2}\right): \delta 78.8$. ESI-MS: $m / z 821\left([\mathrm{M}]^{+}\right), 793\left([\mathrm{M}-\mathrm{CO}]^{+}\right)$. IR $\left(\mathrm{CH}_{2} \mathrm{Cl}_{2}\right): v_{\mathrm{CO}} 1956 \mathrm{~cm}^{-1}$. Anal. Calcd for $\mathrm{C}_{44} \mathrm{H}_{37} \mathrm{BF}_{4} \mathrm{FeNiOP}_{2} \mathrm{~S}_{2} \cdot 0.5 \mathrm{CH}_{2} \mathrm{Cl}_{2}$ (found): $\mathrm{C}$, 56.16 (56.08); H, 4.02 (4.19).

\section{$\left(\mathrm{C}_{5} \mathrm{H}_{5}\right) \mathrm{Ni}(\mathrm{pdt}) \mathrm{Fe}(\mathrm{dppe})(\mathrm{CO})\left([1 \mathrm{a}]^{0}\right)$}

To a stirred solution of [1a]BF 4 (21.2 mg, $26.5 \mu \mathrm{mol})$ in THF ( $3 \mathrm{~mL})$ was added cobaltocene (5.8 $\mathrm{mg}, 30.7 \mu \mathrm{mol}$ ) in THF ( $3 \mathrm{~mL}$ ). The solution immediately darkened, and solid $\left[\left(\mathrm{C}_{5} \mathrm{H}_{5}\right)_{2} \mathrm{Co}\right] \mathrm{BF}_{4}$ precipitated. The solvent is removed under reduced pressure, and the product was extracted into toluene $(2 \mathrm{~mL})$. The slurry was filtered through diatomaceous earth to yield a homogeneous, brown-black solution. The product is crystallized upon the addition of pentane $(15 \mathrm{~mL})$. Yield: $17.0 \mathrm{mg}(90 \%)$, black powder. Single crystals were obtained by vapor diffusion of pentane into concentrated toluene solutions. IR $\left(\mathrm{CH}_{2} \mathrm{Cl}_{2}\right)$ : 
$\tilde{v_{\mathrm{CO}}} 1901 \mathrm{~cm}^{-1}$. Anal. Calcd for $\mathrm{C}_{35} \mathrm{H}_{35} \mathrm{FeNiOP}_{2} \mathrm{~S}_{2}$ (found): $\mathrm{C}, 59.02$ (58.72); H, 4.95

(4.65).

\section{$\left(\mathrm{C}_{5} \mathrm{H}_{5}\right) \mathrm{Ni}(\mathrm{pdt}) \mathrm{Fe}(\mathrm{dppv})(\mathrm{CO})\left(\left[\mathrm{1b}^{0}\right)\right.$}

Compound $[\mathbf{1 b}]^{0}$ was prepared in a fashion similar to that of $[\mathbf{1 a}]^{0}$. Yield: $86 \%$, black powder. IR $\left(\mathrm{CH}_{2} \mathrm{Cl}_{2}\right): \tilde{v_{\mathrm{CO}}} 1903 \mathrm{~cm}^{-1}$.

$\left(\mathrm{C}_{5} \mathrm{H}_{5}\right) \mathrm{Ni}\left(\mathrm{Me}_{2} \mathrm{pdt}\right) \mathrm{Fe}(\mathrm{dppe})(\mathrm{CO})\left([1 \mathrm{c}]^{0}\right)$

Compound $[\mathbf{1 c}]^{0}$ was prepared in a fashion similar to that of $[\mathbf{1 a}]^{0}$. Yield: $87 \%$, black powder. IR $\left(\mathrm{CH}_{2} \mathrm{Cl}_{2}\right): \tilde{v_{\mathrm{CO}}} 1897 \mathrm{~cm}^{-1}$.

\section{$\left(\mathrm{CH}_{3} \mathrm{C}_{5} \mathrm{H}_{4}\right) \mathrm{Ni}(\mathrm{pdt}) \mathrm{Fe}(\mathrm{dppe})(\mathrm{CO})\left([1 \mathrm{~d}]^{0}\right)$}

Compound $[\mathbf{1 d}]^{0}$ was prepared in a fashion similar to that of $[\mathbf{1 a}]^{0}$. Yield: $80 \%$, black powder. IR $\left(\mathrm{CH}_{2} \mathrm{Cl}_{2}\right): v_{\mathrm{CO}} 1898 \mathrm{~cm}^{-1}$.

\section{$\left(C_{5} D_{5}\right) \mathrm{Ni}(\mathrm{pdt}) \mathrm{Fe}(\mathrm{dppe})(\mathrm{CO})\left(\left[1 \mathrm{a}-d_{5}\right]^{0}\right)$}

Compound $\left[\mathbf{1 a}-d_{5}\right]^{0}$ was prepared in a fashion similar to that of $[\mathbf{1 a}]^{0}$.

\section{$\left(\mathrm{C}_{5} \mathrm{H}_{5}\right) \mathrm{Ni}(\mathrm{SPh})_{2} \mathrm{Fe}(\mathrm{dppv})(\mathrm{CO})\left([2 \mathrm{~b}]^{0}\right)$}

Compound $[\mathbf{2 b}]^{0}$ was prepared in a fashion similar to that of $[\mathbf{1 a}]^{0}$. Yield: $61 \%$, black powder. IR $\left(\mathrm{CH}_{2} \mathrm{Cl}_{2}\right): v_{\mathrm{CO}} 1915 \mathrm{~cm}^{-1}$. Single crystals of $[\mathbf{2 b}]^{0}$ were obtained by vapor diffusion of pentane into concentrated toluene solutions.

\section{COMPUTATIONAL METHODS}

DFT results reported herein were performed using the BP86 density functional. ${ }^{58,59}$ Additional benchmarking was performed using the B3P86, ${ }^{58,60}$ BP86-D2, ${ }^{58,59,61}$ M06-L, ${ }^{62}$ and $\omega \mathrm{B} 97 \mathrm{XD}^{61,63-65}$ functionals and is presented in Tables S1-S7. The DFT calculations were performed with the Stuttgart pseudopotential and associated basis set of Preuss and coworkers (SDD) ${ }^{66}$ for the nickel and iron centers, the $6-31 \mathrm{G}^{* *}$ basis set ${ }^{67}$ for the $\mu$-hydrogen ligand, and the $6-31 \mathrm{G}^{*}$ basis set ${ }^{68,69}$ for all other atoms. The starting geometries for [1a$\mathbf{1 d}]^{+},[\mathbf{1 a}]^{0}$, and $[\mathbf{2 b}]^{0}$ were obtained from their respective crystal structures. The starting coordinates for species without crystal structures were obtained by manual alteration of the most closely related crystal structure. Solvation free energies were calculated in $\mathrm{CH}_{2} \mathrm{Cl}_{2}$ using the conductor-like polarizable continuum model (C-PCM $)^{70,71}$ with the Bondi atomic radii ${ }^{72}$ and including the nonelectrostatic contributions of dispersion, ${ }^{73,74}$ repulsion, ${ }^{73,74}$ and cavitation energies. ${ }^{75}$

For the results presented in the main paper, geometry optimizations were performed in the gas phase. However, geometry optimizations were also performed in solution and were found to be consistent with the gas-phase optimizations. A comparison of the structures optimized in the gas and solution phases is provided in Tables S4-S7. In all cases, the minimum-energy structures were confirmed to have no imaginary frequencies. The $v_{\mathrm{CO}}$ frequencies were calculated within the harmonic model. Typically, DFT is more reliable for calculating changes in the frequencies than the absolute frequencies, and often scaling 
factors dependent on the functional are used ${ }^{76}$ Herein, however, the absolute $\tilde{v_{\mathrm{CO}}}$ values are reported because the BP86 functional gives excellent agreement with the experimental values without the application of scaling factors. Nonetheless, $\Delta v_{\mathrm{CO}}$ values calculated using different functionals are provided in Table S3. The TSs for isomerization of the Fe(dppe) (CO) subunit were identified using the synchronous transit-guided quasi-Newton method, ${ }^{77,78}$ and the TSs were confirmed to have only one imaginary frequency. Each TS was verified to lead to the relevant dibasal or apical-basal isomers by following the intrinsic reaction coordinate using the local quadratic approximation ${ }^{79,80}$ for $5-10$ steps in the forward and reverse directions and subsequently optimizing the geometries.

Thermochemical data were calculated at $T=298.15 \mathrm{~K}$. All calculated free energies included zero-point energy, entropic contributions, and solvation effects. The reaction free energies $\left(\Delta G^{\circ}\right)$ and free energy barriers $\left(\Delta G^{\ddagger}\right)$ associated with isomerization of the $\mathrm{Fe}(\mathrm{dppe})(\mathrm{CO})$ subunit in solution were calculated from the optimized geometries and TSs. The relative reduction potentials were calculated from the corresponding reaction free energies using a methodology described elsewhere. ${ }^{81-84}$ Chemical bonding analysis was performed using the Pipek-Mezey localization criteria, ${ }^{44}$ using keyword IOp(4/9=20212), and NBOs. ${ }^{45}$ All calculations were performed using the Gaussian 09 electronic structure program. ${ }^{85}$ Structures and energies of the systems studied herein are provided in Tables S12-S73.

\section{Supplementary Material}

Refer to Web version on PubMed Central for supplementary material.

\section{Acknowledgments}

The synthesis work was supported by the National Institutes of Health through Grant GM061153 and the International Center of Carbon-Neutral Energy Research. We thank Bernd Mienert for the Mössbauer measurements and Dr. Eckhard Bill for insight into their interpretation. We also thank Katharina Weber for help with sample preparation and preliminary DFT calculations. The computational portion of this work was funded by the National Science Foundation Graduate Research Fellowship Program under Grant DGE-1144245 (to M.T.H.) and by the National Science Foundation Center for Chemical Innovation under Grant CHE-1305124. We thank Dr. Danielle Gray for assistance with the X-ray crystallographic analysis.

\section{References}

1. Bullock RM, Appel AM, Helm ML. Chem Commun. 2014; 50:3125.

2. Wang M, Chen L, Sun L. Energy Environ Sci. 2012; 5:6763.

3. Lansing, JC.; Manor, BC.; Rauchfuss, TB. Encyclopedia of Inorganic and Bioinorganic Chemistry. Scott, RA., editor. John Wiley; Chichester, U.K: 2014.

4. Schollhammer, P.; Weigand, W., editors. Bioinspired Catalysis. Wiley-VCH; Weinheim, Germany: 2014.

5. Frey M. Chem Bio Chem. 2002; 3:153.

6. Lubitz W, Ogata H, Rüdiger O, Reijerse E. Chem Rev. 2014; 114:4081. [PubMed: 24655035]

7. Tard C, Pickett CJ. Chem Rev. 2009; 109:2245. [PubMed: 19438209]

8. Parkin A, Sargent F. Curr Opin Chem Biol. 2012; 16:26. [PubMed: 22366384]

9. Wulff P, Day CC, Sargent F, Armstrong FA. Proc Natl Acad Sci U S A. 2014; 111:6606. [PubMed: 24715724]

10. Berggren G, Adamska A, Lambertz C, Simmons TR, Esselborn J, Atta M, Gambarelli S, Mouesca JM, Reijerse E, Lubitz W, Happe T, Artero V, Fontecave M. Nature. 2013; 499:66. [PubMed: 23803769] 
11. Carroll ME, Barton BE, Rauchfuss TB, Carroll PJ. J Am Chem Soc. 2012; 134:18843. [PubMed: 23126330]

12. Ohki Y, Tatsumi K. Eur J Inorg Chem. 2011; 2011:973.

13. Chiou TW, Liaw WF. C R Chim. 2008; 11:818.

14. Barton BE, Rauchfuss TB. J Am Chem Soc. 2010; 132:14877. [PubMed: 20925337] Manor BC, Rauchfuss TB. J Am Chem Soc. 2013; 135:11895. [PubMed: 23899049]

15. Ogo S, Ichikawa K, Kishima T, Matsumoto T, Nakai H, Kusaka K, Ohhara T. Science. 2013; 339:682. [PubMed: 23393260]

16. Ogata H, Nishikawa K, Lubitz W. Nature. 2015; 520:571. [PubMed: 25624102]

17. Jiang J, Maruani M, Solaimanzadeh J, Lo W, Koch SA, Millar M. Inorg Chem. 2009; 48:6359. [PubMed: 20507106]

18. Krämer T, Kampa M, Lubitz W, van Gastel M, Neese F. Chem Bio Chem. 2013; 14:1898.

19. Kampa M, Lubitz W, van Gastel M, Neese F. JBIC, J Biol Inorg Chem. 2012; 17:1269. [PubMed: 23053531]

20. Schilter D, Nilges MJ, Chakrabarti M, Lindahl PA, Rauchfuss TB, Stein M. Inorg Chem. 2012; 51:2338-2348. [PubMed: 22304696]

21. Huynh MT, Schilter D, Hammes-Schiffer S, Rauchfuss TB. J Am Chem Soc. 2014; 136:12385. [PubMed: 25094041]

22. Carroll ME, Chen J, Gray DE, Lansing JC, Rauchfuss TB, Schilter D, Volkers PI, Wilson SR. Organometallics. 2014; 33:858. [PubMed: 24803716]

23. De Lacey AL, Fernández VM, Rousset M, Cammack R. Chem Rev. 2007; 107:4304. [PubMed: 17715982]

24. Siegbahn PEM, Tye JW, Hall MB. Chem Rev. 2007; 107:4414. [PubMed: 17927160]

25. Wu H, Hall MB. C R Chim. 2008; 11:790.

26. Hidalgo R, Ash PA, Healy AJ, Vincent KA. Angew Chem, Int Ed. 2015; 54:7110.

27. Greene BL, Wu CH, McTernan PM, Adams MWW, Dyer RB. J Am Chem Soc. 2015; 137:4558. [PubMed: 25790178]

28. Schilter D, Rauchfuss TB, Stein M. Inorg Chem. 2012; 51:8931. [PubMed: 22838645]

29. Priego JL, Doerrer LH, Rees LH, Green MLH. Chem Commun. 2000:779.

30. Seiler P, Dunitz JD. Acta Crystallogr, Sect B: Struct Crystallogr Cryst Chem. 1980; 36:2255.

31. Byers LR, Dahl LF. Inorg Chem. 1980; 19:680.

32. Lubitz, W.; van Gastel, M.; Gärtner, W. Nickel and Its Surprising Impact in Nature. Sigel, A.; Sigel, H.; Sigel, RKO., editors. Wiley-VCH; Weinheim, Germany: 2007. p. 279

33. Carroll ME, Chen JZ, Gray DE, Lansing JC, Rauchfuss TB, Schilter D, Volkers PI, Wilson SR. Organometallics. 2014; 33:858. [PubMed: 24803716]

34. Kellers P, Pandelia ME, Currell LJ, Görner H, Lubitz W. Phys Chem Chem Phys. 2009; 11:8680. [PubMed: 20449009]

35. Pandelia ME, Infossi P, Stein M, Giudici-Orticoni MT, Lubitz W. Chem Commun. 2012; 48:823.

36. Kampa M, Pandelia ME, Lubitz W, van Gastel M, Neese F. J Am Chem Soc. 2013; 135:3915. [PubMed: 23402569]

37. Gütlich, P.; Bill, E.; Trautwein, AX. Mössbauer Spectroscopy and Transition Metal Chemistry. Fundamentals and Applications. Springer; Berlin: 2011.

38. Pandelia ME, Bykov D, Izsak R, Infossi P, Giudici-Orticoni MT, Bill E, Neese F, Lubitz W. Proc Natl Acad Sci U S A. 2013; 110:483. [PubMed: 23267108]

39. Surerus KK, Chen M, van der Zwaan JW, Rusnak FM, Kolk M, Duin EC, Albracht SPJ, Muenck E. Biochemistry. 1994; 33:4980. [PubMed: 8161560]

40. Pereira AS, Tavares P, Moura I, Moura JJG, Huynh BH. J Am Chem Soc. 2001; 123:2771.

[PubMed: 11456963]

41. Popescu CV, Münck E. J Am Chem Soc. 1999; 121:7877.

42. Zhu W, Marr AC, Wang Q, Neese F, Spencer DJE, Blake AJ, Cooke PA, Wilson C, Schröder M. Proc Natl Acad Sci U S A. 2005; 102:18280. [PubMed: 16352727] 
43. Schilter D, Pelmenschikov V, Wang H, Meier F, Gee LB, Yoda Y, Kaupp M, Rauchfuss TB, Cramer SP. Chem Commun. 2014; 50:13469.

44. Pipek J, Mezey PG. J Chem Phys. 1989; 90:4916.

45. Glendening, ED.; Reed, AE.; Carpenter, JE.; Weinhold, F. NBO. University of Wisconsin System; Madison, WI: 1996. version 3.1

46. Pool DH, DuBois DL. J Organomet Chem. 2009; 694:2858.

47. Wang W, Rauchfuss TB, Moore CE, Rheingold AL, De Gioia L, Zampella G. Chem - Eur J. 2013; 19:15476. [PubMed: 24130068]

48. Li Z, Ohki Y, Tatsumi K. J Am Chem Soc. 2005; 127:8950. [PubMed: 15969562]

49. Pandelia ME, Ogata H, Currell LJ, Flores M, Lubitz W. Biochim Biophys Acta, Bioenerg. 2010; 1797:304.

50. Weber K, Krämer T, Shafaat HS, Weyhermüller T, Bill E, van Gastel M, Neese F, Lubitz W. J Am Chem Soc. 2012; 134:20745. [PubMed: 23194246]

51. Chambers GM, Mitra J, Rauchfuss TB, Stein M. Inorg Chem. 2014; 53:4243. [PubMed: 24684697]

52. Tschierlei S, Ott S, Lomoth R. Energy Environ Sci. 2011; 4:2340.

53. Gloaguen F, Rauchfuss TB. Chem Soc Rev. 2009; 38:100. [PubMed: 19088969]

54. Reijerse E, Lendzian F, Isaacson R, Lubitz W. J Magn Reson. 2012; 214:237. [PubMed: 22196894]

55. Stoll S, Schweiger A. J Magn Reson. 2006; 178:42. [PubMed: 16188474]

56. Salzer A, Werner H. Angew Chem, Int Ed Engl. 1972; 11:930.

57. de Beer JA, Haines RJ. J Organomet Chem. 1972; 36:297.

58. Perdew JP. Phys Rev B: Condens Matter Mater Phys. 1986; 33:8822.

59. Becke AD. Phys Rev A: At, Mol, Opt Phys. 1988; 38:3098.

60. Becke AD. J Chem Phys. 1993; 98:5648.

61. Grimme S. J Comput Chem. 2006; 27:1787. [PubMed: 16955487]

62. Zhao Y, Truhlar DG. J Chem Phys. 2006; 125:194101. [PubMed: 17129083]

63. Becke AD. J Chem Phys. 1997; 107:8554.

64. Kamiya M, Tsuneda T, Hirao K. J Chem Phys. 2002; 117:6010.

65. Chai JD, Head-Gordon M. Phys Chem Chem Phys. 2008; 10:6615. [PubMed: 18989472]

66. Dolg M, Wedig U, Stoll H, Preuss H. J Chem Phys. 1987; 86:866.

67. Hariharan PC, Pople JA. Theoret Chim Acta. 1973; 28:213.

68. Hehre WJ, Ditchfield R, Pople JA. J Chem Phys. 1972; 56:2257.

69. Francl MM, Pietro WJ, Hehre WJ, Binkley JS, Gordon MS, DeFrees DJ, Pople JA. J Chem Phys. 1982; 77:3654.

70. Barone V, Cossi M. J Phys Chem A. 1998; 102:1995.

71. Cossi M, Rega N, Scalmani G, Barone V. J Comput Chem. 2003; 24:669. [PubMed: 12666158]

72. Bondi A. J Phys Chem. 1964; 68:441.

73. Floris F, Tomasi J. J Comput Chem. 1989; 10:616.

74. Floris FM, Tomasi J, Ahuir JLP. J Comput Chem. 1991; 12:784.

75. Pierotti RA. Chem Rev. 1976; 76:717.

76. Alecu IM, Zheng J, Zhao Y, Truhlar DG. J Chem Theory Comput. 2010; 6:2872. [PubMed: 26616087]

77. Peng C, Bernhard Schlegel H. Isr J Chem. 1993; 33:449.

78. Peng C, Ayala PY, Schlegel HB, Frisch MJ. J Comput Chem. 1996; 17:49.

79. Page M, McIver JW. J Chem Phys. 1988; 88:922.

80. Koseki S, Gordon MS. J Phys Chem. 1989; 93:118.

81. Solis BH, Hammes-Schiffer S. Inorg Chem. 2011; 50:11252. [PubMed: 21942543]

82. Fernandez LE, Horvath S, Hammes-Schiffer S. J Phys Chem C. 2012; 116:3171.

83. Solis BH, Hammes-Schiffer S. Inorg Chem. 2014; 53:6427. [PubMed: 24731018]

Inorg Chem. Author manuscript; available in PMC 2017 January 19. 
84. Qi XJ, Fu Y, Liu L, Guo QX. Organometallics. 2007; 26:4197.

85. Frisch, MJ.; Trucks, GW.; Schlegel, HB.; Scuseria, GE.; Robb, MA.; Cheeseman, JR.; Scalmani, G.; Barone, V.; Mennucci, B.; Petersson, GA.; Nakatsuji, H.; Caricato, M.; Li, X.; Hratchian, HP.; Izmaylov, AF.; Bloino, J.; Zheng, G.; Sonnenberg, JL.; Hada, M.; Ehara, M.; Toyota, K.; Fukuda, R.; Hasegawa, J.; Ishida, M.; Nakajima, T.; Honda, Y.; Kitao, O.; Nakai, H.; Vreven, T.;

Montgomery, JA., Jr; Peralta, JE.; Ogliaro, F.; Bearpark, M.; Heyd, JJ.; Brothers, E.; Kudin, KN.;

Staroverov, VN.; Kobayashi, R.; Normand, J.; Raghavachari, K.; Rendell, A.; Burant, JC.;

Iyengar, SS.; Tomasi, J.; Cossi, M.; Rega, N.; Millam, JM.; Klene, M.; Knox, JE.; Cross, JB.;

Bakken, V.; Adamo, C.; Jaramillo, J.; Gomperts, R.; Stratmann, RE.; Yazyev, O.; Austin, AJ.;

Cammi, R.; Pomelli, C.; Ochterski, JW.; Martin, RL.; Morokuma, K.; Zakrzewski, VG.; Voth,

GA.; Salvador, P.; Dannenberg, JJ.; Dapprich, S.; Daniels, AD.; Farkas; Foresman, JB.; Ortiz, JV.;

Cioslowski, J.; Fox, DJ. Gaussian 09. Gaussian, Inc; Wallingford, CT: 2010. revision D.01

86. Roncaroli F, Bill E, Friedrich B, Lenz O, Lubitz W, Pandelia ME. Chem Sci. 2015; 6:4495-4507. 

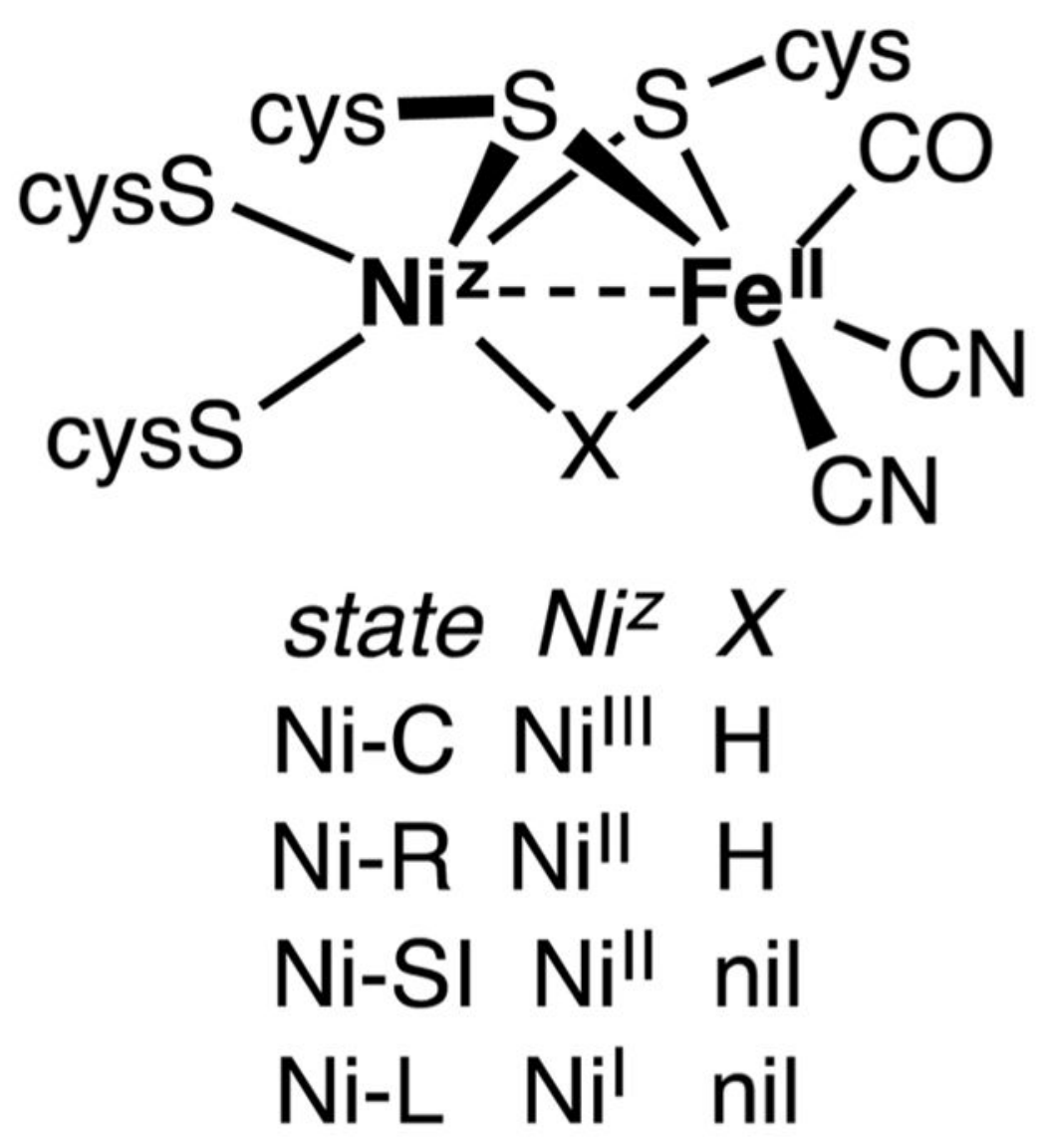

Figure 1.

States of the active site of the [NiFe]-hydrogenases. 


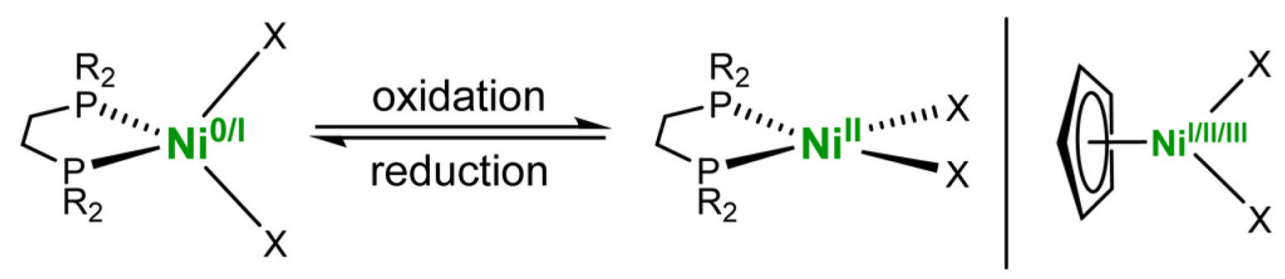

Figure 2.

Nickel diphosphine complexes changing geometry upon the oxidation of tetrahedral $\mathrm{Ni}^{0 / I}$. The $\mathrm{Ni}\left(\mathrm{C}_{5} \mathrm{H}_{5}\right)$ center is structurally invariant over three oxidation states. 


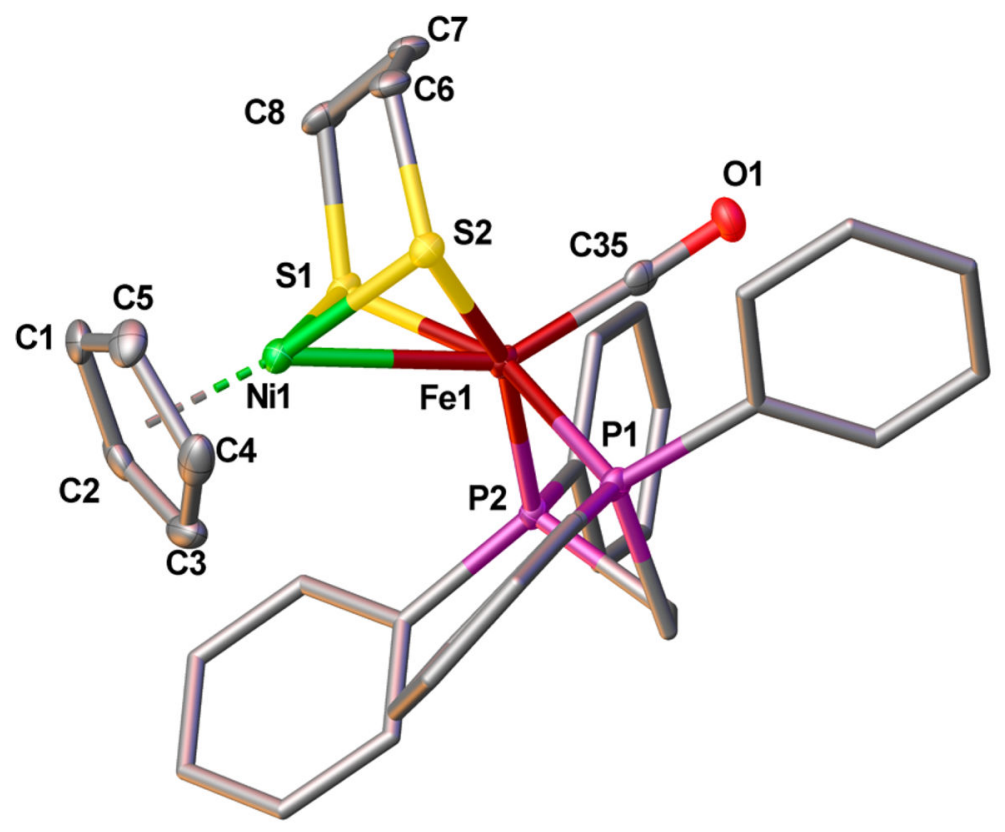

Figure 3.

Solid-state structure of $[\mathbf{1 a}] \mathrm{BF}_{4}$ shown at the $50 \%$ probability level. Hydrogen atoms, counterions, and solvent have been omitted for clarity. Selected bond distances $(\AA)$ : Ni1Fe1, 2.5145(4); Ni1-centroid, 1.722(3); Ni1-S ${ }_{\text {avg }}$, 2.1645(7); Fe1-S ${ }_{\text {avg }}$, 2.2208(7); Fe1C35, 1.757(2); C35-O1, 1.147(2). 


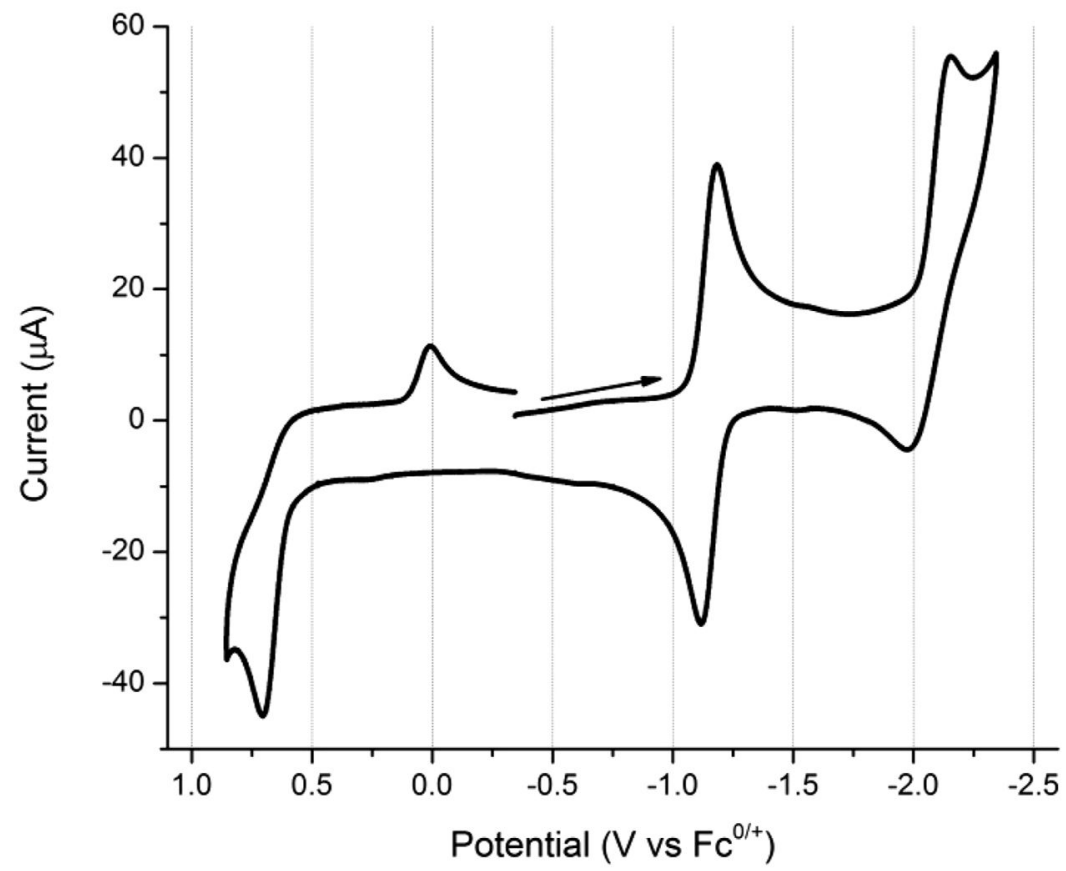

Figure 4.

Cyclic voltammogram of $[\mathbf{1 a}] \mathrm{BF}_{4}$ at $500 \mathrm{mV} \mathrm{s}^{-1}$. Conditions: $\sim 1 \mathrm{mM}$ in $\mathrm{CH}_{2} \mathrm{Cl}_{2} ; 100 \mathrm{mM}$ $\left[\mathrm{NBu}_{4}\right] \mathrm{PF}_{6}$; glassy carbon electrode $(d=3 \mathrm{~mm})$; silver wire as the pseudoreference with an internal Fc standard at $0 \mathrm{~V}$; platinum as the counter electrode. 


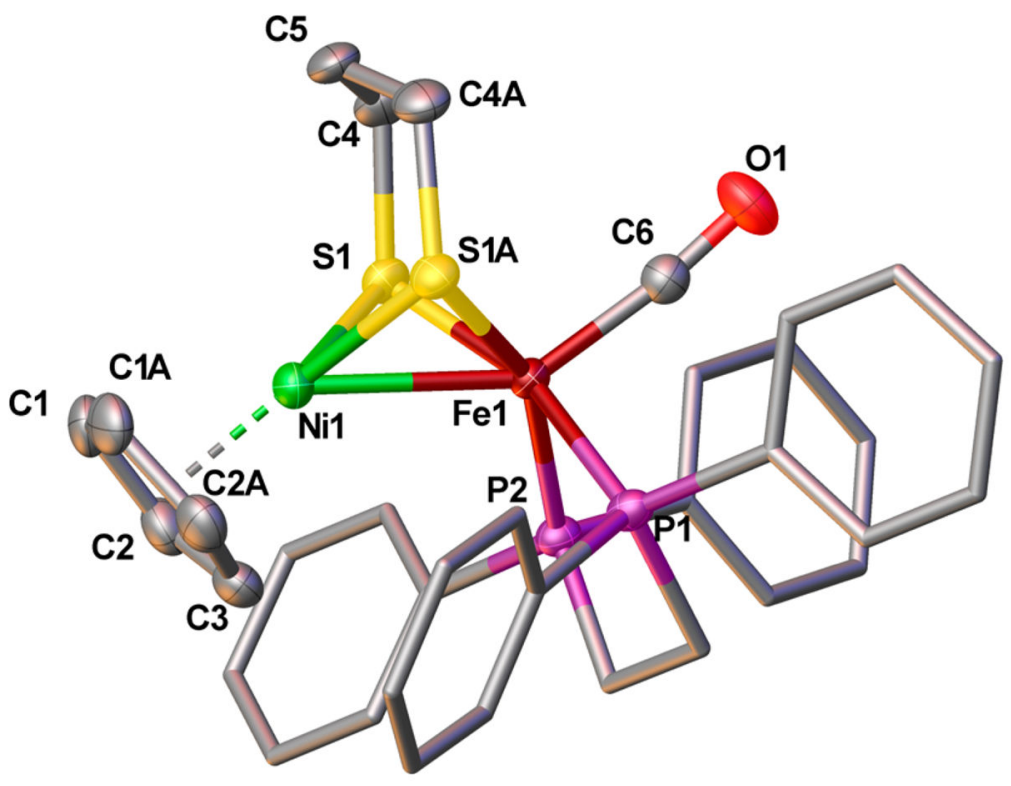

Figure 5.

Solid-state structure of $[\mathbf{1 a}]^{0}$ shown at the $50 \%$ probability level. Hydrogen atoms and solvent have been omitted for clarity. Selected bond distances ( $\AA$ ): Ni1-Fe1, 2.4593(6);

Ni1-centroid, 1.795(3); Ni1-S $\mathrm{avg}_{\text {g }}$, 2.2772(5); Fe1-S $\mathrm{avg}_{\mathrm{avg}}$ 2.2544(5); Fe1-C6, 1.745(3); C6O1, 1.159(3). 

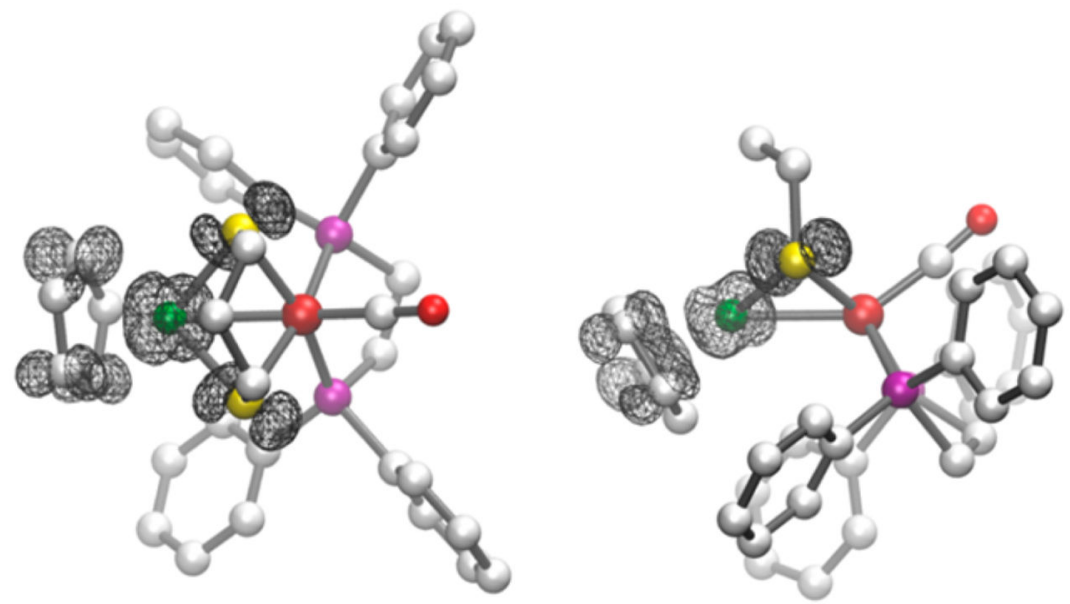

Figure 6.

Views of the isocontour plot of the positive spin density for $[\mathbf{1 a}]^{0}$ from two perspectives. The spin density is localized about the nickel coordination sphere. Color scheme: green, nickel; maroon, iron; yellow, sulfur; purple, phosphorus; red, oxygen; white, carbon. The hydrogen atoms have been removed for clarity. 


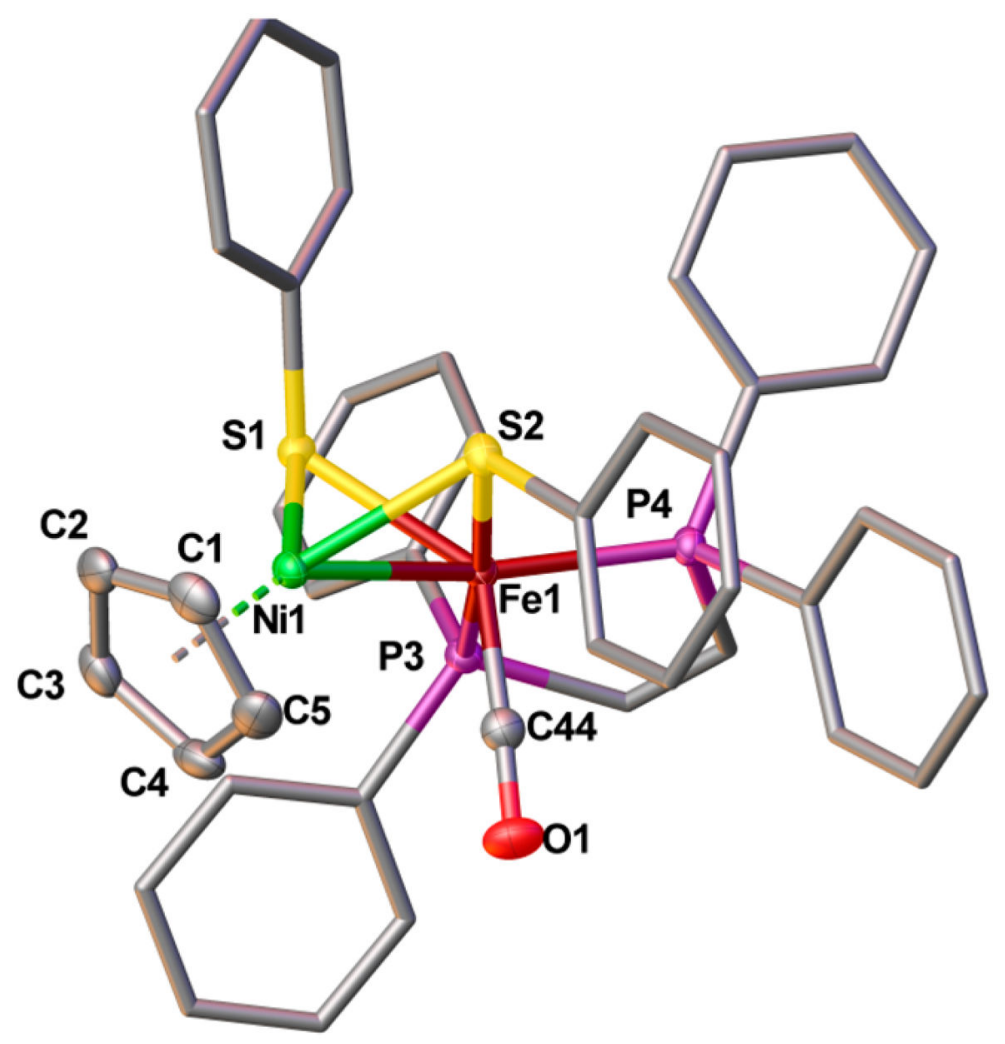

Figure 7.

Solid-state structure of $[\mathbf{2 b}]^{0}$ shown at the $50 \%$ probability level. Hydrogen atoms and solvent have been omitted for clarity. Selected bond distances ( $\mathrm{A})$ : Ni1-Fe1, 2.4594(3); Ni1-centroid, 1.817(2); Ni1-S ${ }_{\text {avg }}, 2.3067(5) ; ~ F e 1-S_{\text {avg }}, 2.2868(5) ; ~ F e 1-P_{\text {avg }}, 2.1934(5)$; Fe1-C44, 1.738(2); C44-O1, 1.162(2). 


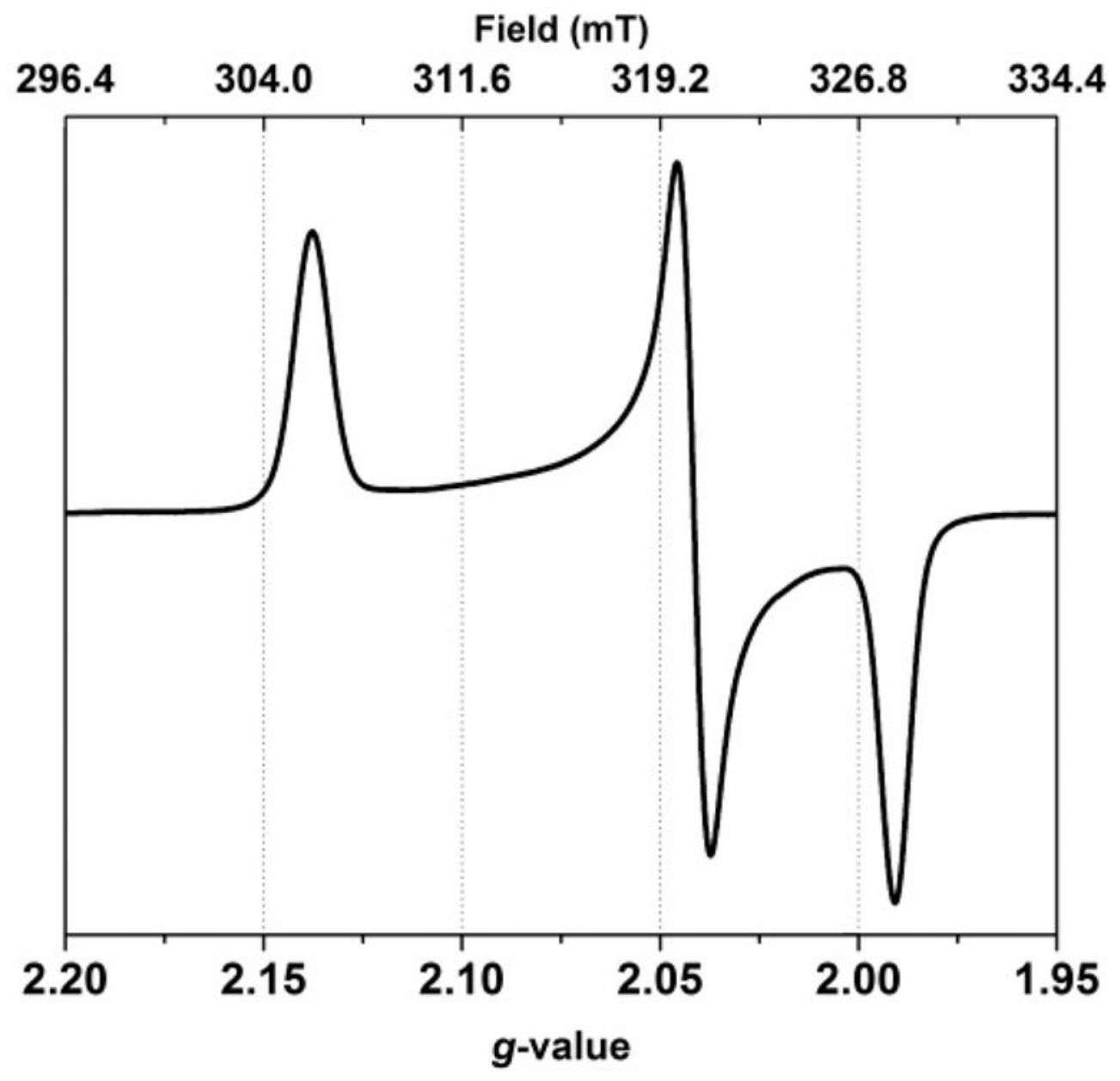

Figure 8.

$\mathrm{X}$-band CW-EPR spectrum of a $\sim 2 \mathrm{mM}$ frozen solution of $[\mathbf{1 a}]^{0}$ in $1: 1 \mathrm{CH}_{2} \mathrm{Cl}_{2} / \mathrm{THF}(110$ $\mathrm{K})$. 

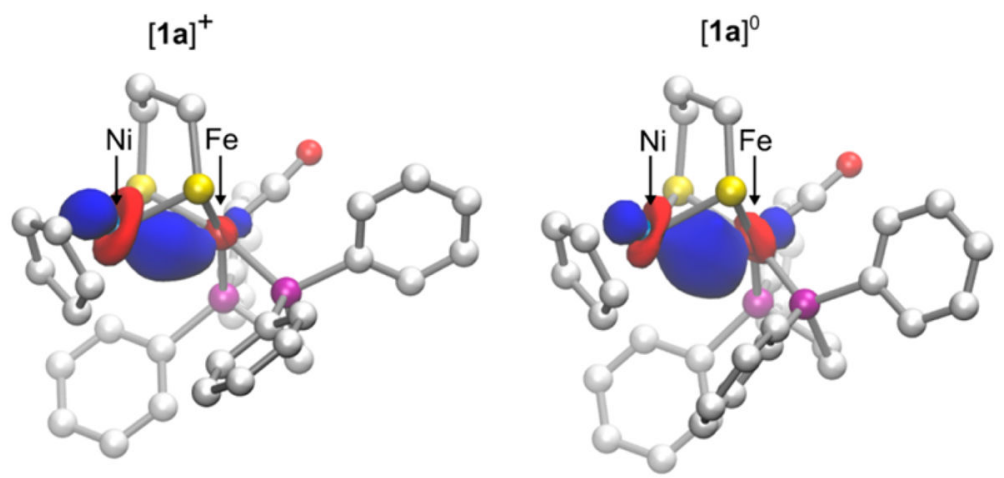

Figure 9.

Pipek-Mezey localized MOs showing the Ni-Fe $\sigma$ bonds in $[\mathbf{1 a}]^{+}$and $[\mathbf{1 a}]^{0}$. The composition of the $\mathrm{MO}$ in [1a] $]^{+}$is $85 \%$ nickel and $15 \%$ iron, and the composition of the MO in [1a] $]^{0}$ is $53 \%$ nickel and $47 \%$ iron. Only the $a$ orbital is shown for $[\mathbf{1 a}]^{0}$; however, the $\beta$ orbital is similar. 


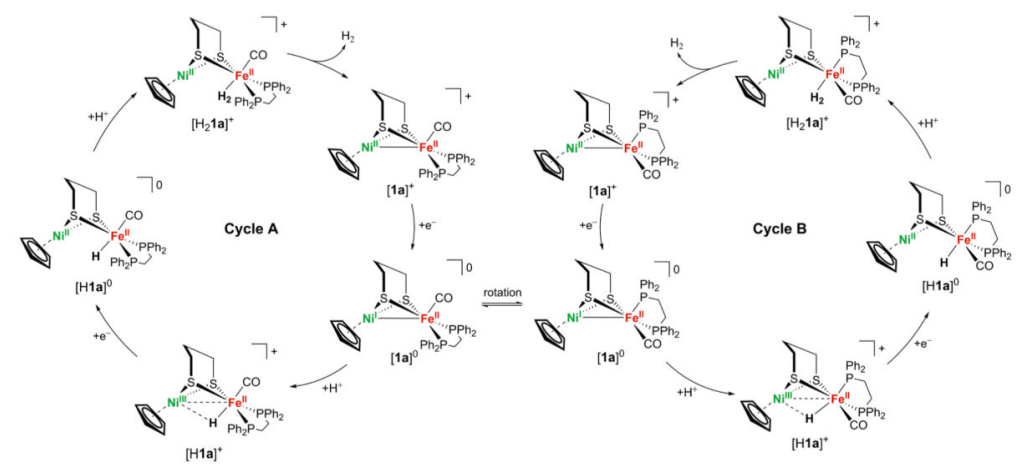

Figure 10.

Proposed mechanism for $\mathrm{H}_{2}$ production proceeding through two isomers. Cycle $\mathrm{A}$, on the left, proceeds through structures in which the dppe ligand is in the dibasal position. Cycle B, on the right, proceeds through structures in which the dppe ligand spans apical-basal positions. Isomerization of $[\mathbf{1 a}]^{0}$, which has the lowest free energy barrier, could lead to a transition between cycles $\mathrm{A}$ and $\mathrm{B}$. 


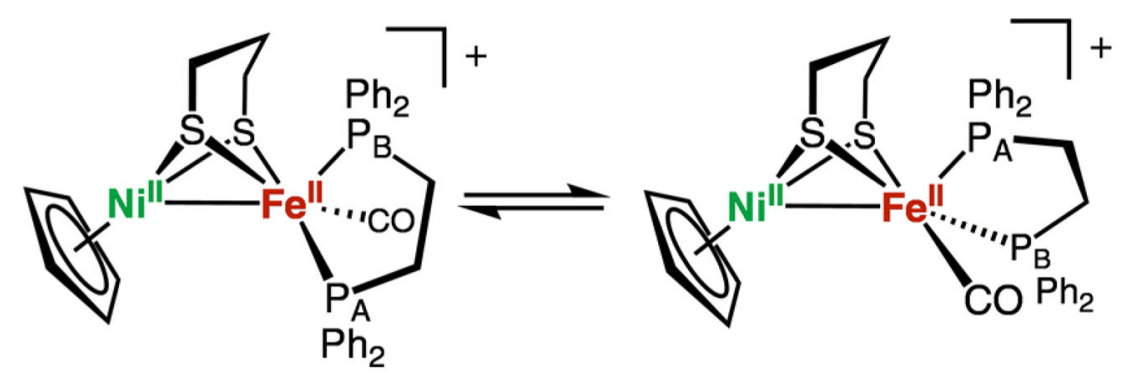

Figure 11.

Representation of the iron-centered rocking motion in $\left[\mathbf{1 a}^{\mathbf{B}}\right]^{+}$. 


$$
\begin{aligned}
& \text { Step A: }[\mathbf{1} \mathbf{a}]^{0}+\mathrm{H}^{+} \rightarrow[\mathrm{H} \mathbf{1} \mathbf{a}]^{+} \\
& \text {Step B: }[\mathrm{H} \mathbf{1} \mathbf{a}]^{+}+[\mathbf{1} \mathbf{a}]^{0} \rightarrow[\mathrm{H} \mathbf{1} \mathbf{a}]^{0}+[\mathbf{1} \mathbf{a}]^{+} \\
& \text {Step C: }[\mathrm{H} \mathbf{1} \mathbf{a}]^{0}+\mathrm{H}^{+} \rightarrow[\mathbf{1} \mathbf{a}]^{+}+\mathrm{H}_{2}
\end{aligned}
$$

Scheme 1. 
Table 1

Summary of Models for the Active States of the [NiFe]-Hydrogenase ${ }^{a}$

\begin{tabular}{|c|c|c|c|}
\hline state & core description & state of the art models & comment \\
\hline $\mathrm{Ni}-\mathrm{R}$ & $\mathrm{Ni}^{\mathrm{II}}-\mathrm{H}-\mathrm{Fe}^{\mathrm{II}}$ & $\begin{array}{l}{\left[(\text { diphos }) \mathrm{Ni}(\mathrm{pdt})(\mu-\mathrm{H}) \mathrm{Fe}(\mathrm{CO})_{2} \mathrm{~L}\right]^{+14}} \\
{\left[(\text { amine })_{2} \mathrm{Ni}(\mathrm{SR})_{2}(\mu-\mathrm{H}) \mathrm{FeL}_{3}\right]^{+15}}\end{array}$ & $\begin{array}{l}\text { models: } d_{\mathrm{Fe}-\mathrm{H}}<d_{\mathrm{Ni}-\mathrm{H}} \\
\text { enzyme: } d_{\mathrm{Fe}-\mathrm{H}}>d_{\mathrm{Ni}-\mathrm{H}}{ }^{16}\end{array}$ \\
\hline Ni-SI & $\mathrm{Ni}^{\mathrm{II}}{ }_{-}-\mathrm{Fe}^{\mathrm{II}}$ & {$\left[(\text { diphos }) \mathrm{Ni}(\mathrm{SR})_{2} \mathrm{Fe}(\mathrm{CO})_{2} \mathrm{~L}_{2}\right]^{+17}$} & $\begin{array}{l}\text { model: six-coordinated iron } \\
\text { enzyme: five-coordinated iron }{ }^{18}\end{array}$ \\
\hline $\mathrm{Ni}-\mathrm{C}$ & $\mathrm{Ni}^{\mathrm{III}}-\mathrm{H}-\mathrm{Fe}^{\mathrm{II}} 19$ & none & no progress \\
\hline Ni-L & $\mathrm{Ni}^{\mathrm{I}}-{ }_{-}-\mathrm{Fe}^{\mathrm{II}}$ & {$\left[(\mathrm{diphos}) \mathrm{Ni}(\mathrm{pdt}) \mathrm{Fe}(\mathrm{CO})_{2} \mathrm{~L}\right]^{+20}$} & model: $\mathrm{Ni}^{\mathrm{II}} \mathrm{Fe}^{\mathrm{I}}$ vs enzyme: $\mathrm{Ni}^{\mathrm{I}} \mathrm{Fe}^{\mathrm{II}} 16$ \\
\hline
\end{tabular}


Table 2

IR Data for Compounds [1a-1d] $\mathrm{BF}_{4}$ and [2b]BF 4 in a $\mathrm{CH}_{2} \mathrm{Cl}_{2}$ Solution and the Ni-SI Organisms

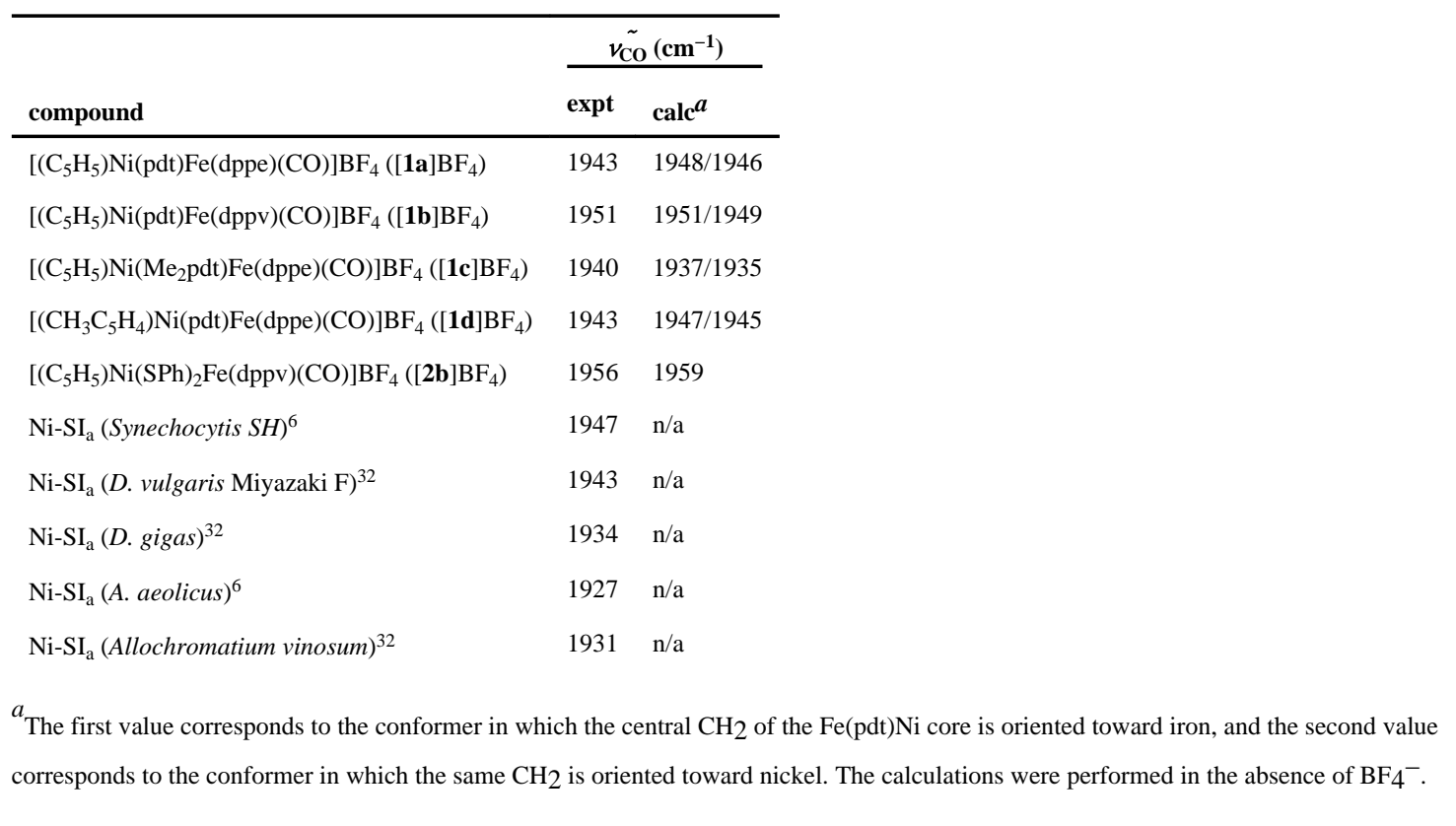




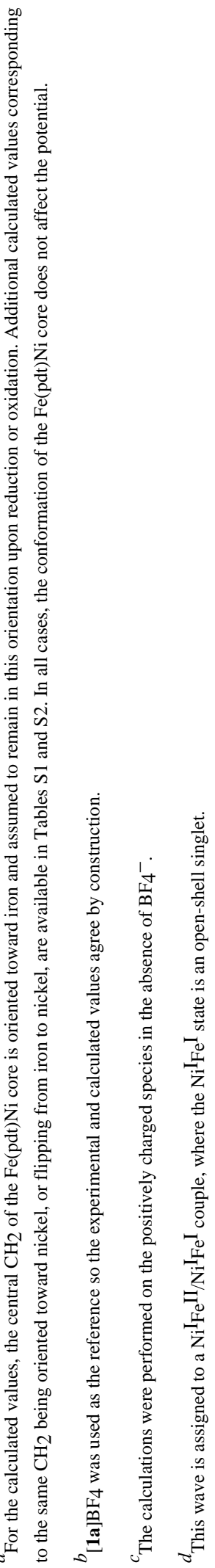


Table 4

IR Data for $\tilde{v_{\mathrm{CO}}}$ in Compounds $[1 \mathrm{a}-1 \mathrm{~d}]^{0}$ and $[2 \mathrm{~b}]^{0}$ in a $\mathrm{CH}_{2} \mathrm{Cl}_{2}$ Solution

\begin{tabular}{cll}
\hline & \multicolumn{2}{c}{$\tilde{\nu_{\mathbf{C O}}\left(\mathbf{c m}^{-\mathbf{1}}\right)}$} \\
\cline { 2 - 3 } compound & $\mathbf{\text { expt }}$ & calc $^{\boldsymbol{a}}$ \\
\hline$[\mathbf{1 a}]^{0}$ & 1901 & $1901 / 1901$ \\
{$[\mathbf{1 b}]^{0}$} & 1903 & $1909 / 1906$ \\
{$[\mathbf{1 c}]^{0}$} & 1897 & $1898 / 1899$ \\
{$[\mathbf{1 d}]^{0}$} & 1898 & $1900 / 1900$ \\
{$[\mathbf{2 b}]^{0}$} & 1915 & 1911
\end{tabular}

${ }^{a}$ The first value corresponds to the isomer in which the central $\mathrm{CH}_{2}$ of the $\mathrm{Fe}(\mathrm{pdt}) \mathrm{Ni}$ core is oriented toward iron, and the second value corresponds to the isomer in which the same $\mathrm{CH}_{2}$ is oriented toward nickel. 


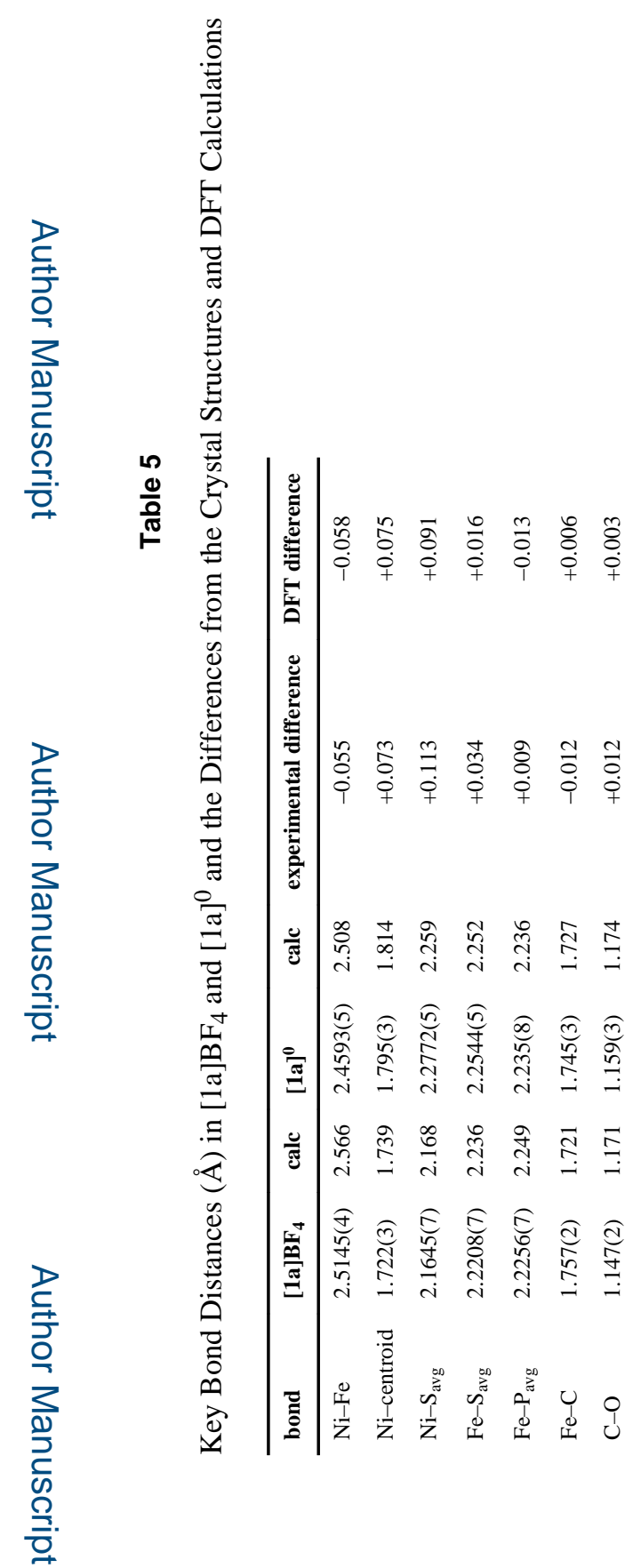

Inorg Chem. Author manuscript; available in PMC 2017 January 19. 


\section{Table 6}

Calculated Spin Densities in Mixed-Valence Species $[1 \mathrm{a}-1 \mathrm{~d}]^{0}$ and $[2 \mathrm{~b}]^{0 a}$

\begin{tabular}{ccccc}
\hline compound & $\mathbf{N i}$ & $\mathbf{F e}$ & $\mathbf{2 S}$ & $\mathbf{C}_{\mathbf{5}} \mathbf{H}_{\mathbf{5}}$ \\
\hline$[\mathbf{1} \mathbf{a}]^{0}$ & 0.71 & -0.17 & 0.24 & 0.24 \\
& 0.71 & -0.19 & 0.23 & 0.25 \\
{$[\mathbf{1 b}]^{0}$} & 0.69 & -0.16 & 0.22 & 0.25 \\
& 0.69 & -0.17 & 0.22 & 0.25 \\
{$[\mathbf{1 c}]^{0}$} & 0.69 & -0.15 & 0.22 & 0.24 \\
& 0.71 & -0.20 & 0.24 & 0.25 \\
{$[\mathbf{1 d}]^{0}$} & 0.69 & -0.17 & 0.23 & $0.25^{b}$ \\
& 0.70 & -0.19 & 0.23 & $0.26^{b}$ \\
{$[\mathbf{2 b}]^{0}$} & 0.72 & -0.20 & 0.20 & 0.26
\end{tabular}

${ }^{a}$ For each complex, the first entry corresponds to the isomer in which the central $\mathrm{CH}_{2}$ of the $\mathrm{Fe}(\mathrm{pdt}) \mathrm{Ni}$ core is oriented toward the $\mathrm{Fe}$ center, and the second entry corresponds to the isomer in which the same $\mathrm{CH}_{2}$ is oriented toward the $\mathrm{Ni}$ center.

${ }^{b}$ For $[\mathbf{1 d}]^{0}$, this is the spin density over the $\mathrm{CH}_{3} \mathrm{C}_{5} \mathrm{H}_{4}$ ligand. 


\section{Table 7}

EPR Parameters for Compounds $[1 \mathrm{a}-1 \mathrm{~d}]^{0}$ and $[2 \mathrm{~b}]^{0}$ (Frozen $\mathrm{CH}_{2} \mathrm{Cl}_{2} /$ Toluene Solution at $110 \mathrm{~K}$ ) and the Ni-L State in Desulfovibrio vulgaris Miyazaki $\mathrm{F}^{6}$

\begin{tabular}{lc}
\hline compound & $\boldsymbol{g}_{\mathbf{1}}, \boldsymbol{g}_{\mathbf{2}}, \boldsymbol{g}_{\mathbf{3}}$ \\
\hline$[\mathbf{1 a}]^{0}$ & $1.991,2.042,2.138$ \\
{$[\mathbf{1 b}]^{0}$} & $1.987,2.042,2.134$ \\
{$[\mathbf{1 c}]^{0}$} & $1.997,2.044,2.138$ \\
{$[\mathbf{1 d}]^{0}$} & $1.987,2.039,2.130$ \\
{$[\mathbf{2 b}]^{0}$} & $1.984,2.039,2.143$ \\
$\mathrm{Ni}-\mathrm{L} 1$ (D. vulgaris) & $2.046,2.118,2.296$
\end{tabular}




\section{Table 8}

Hyperfine Couplings in [1a $]^{0}$ from Q-Band ENDOR and Applied Field Mössbauer Measurements

\begin{tabular}{lccc}
\hline & \multicolumn{3}{c}{ HFI expt (MHz) } \\
\cline { 2 - 4 } nucleus & $\boldsymbol{A}_{\mathbf{1}}$ & $\boldsymbol{A}_{\mathbf{2}}$ & $\boldsymbol{A}_{\mathbf{3}}$ \\
\hline $\mathrm{C}_{5}{ }^{1} \mathrm{H}_{5}$ & -4.86 & +3.25 & -11.25 \\
$\mathrm{CH}_{2}\left(\mathrm{C}^{1} \mathrm{H}_{2} \mathrm{~S}\right)_{2}$ & 7.3 & 4.4 & 4.36 \\
${ }^{31} \mathrm{P}$ & 11.1 & 11.3 & 12.7 \\
${ }^{57} \mathrm{Fe}$ & -3.8 & -0.73 & -0.9
\end{tabular}


Table 9

Mössbauer Parameters for Compounds $[1 \mathrm{a}-1 \mathrm{c}] \mathrm{BF}_{4},[1 \mathrm{a}-1 \mathrm{c}]^{0}$, and $\mathrm{Ni}_{-} \mathrm{SI}_{\mathrm{a}}$ in Regulatory Hydrogenase $(\mathrm{RH})$ from Ralstonia eutropha

\begin{tabular}{lccc}
\hline compound & $\delta$ (mm s$\left.^{-\mathbf{1}}\right)$ & $\boldsymbol{\Delta E}_{\mathbf{q}}{ }^{\boldsymbol{a}}\left(\mathbf{m m ~ s}^{\mathbf{- 1}}\right)$ & $\eta$ \\
\hline$[\mathbf{1} \mathbf{3}] \mathrm{BF}_{4}$ & 0.11 & 1.15 & \\
{$[\mathbf{1 b}] \mathrm{BF}_{4}$} & 0.11 & 1.10 & \\
{$[\mathbf{1 c}] \mathrm{BF}_{4}$} & 0.12 & 0.87 & \\
{$[\mathbf{1 a}]^{0}$} & 0.14 & -0.73 & 0.13 \\
{$[\mathbf{1 b}]^{0}$} & 0.13 & -0.72 & \\
{$[\mathbf{1 c}]^{0}$} & 0.13 & -0.76 & \\
Ni-SIa $R H(\text { R. eutropha })^{86}$ & 0.10 & 1.60 &
\end{tabular}

${ }^{a} \Delta E_{\mathrm{q}}$ signs for $[\mathbf{1 a}-\mathbf{1 c}]^{0}$ are obtained from magnetic Mössbauer spectra. 


\section{Table 11}

Calculated Reaction Free Energies and Free Energy Barriers $\left(\mathrm{kcal} \mathrm{mol}^{-1}\right)$ for Isomerization of Dibasal to Apical-Basal Isomers for $[1 \mathrm{a}]^{0}$ and Its Derivatives in the Proposed Catalytic Cycle ${ }^{a, b, c}$

\begin{tabular}{lll}
\hline compound & $\boldsymbol{\Delta} \boldsymbol{G}^{\circ}$ & $\boldsymbol{\Delta} \boldsymbol{G}^{\ddagger}$ \\
\hline$[\mathbf{1 a}]^{0}$ & 0.48 & 11.76 \\
{$[\mathrm{H} 1 \mathbf{a}]^{+}$} & 2.21 & 20.84 \\
{$[\mathrm{H} \mathbf{1 a}]^{0}$} & 5.18 & 25.64 \\
{$\left[\mathrm{H}_{2} \mathbf{1 a}\right]^{+}$} & 9.86 & 30.03 \\
{$[\mathbf{1} \mathbf{a}]^{+}$} & 2.03 & 21.54
\end{tabular}

${ }^{a}$ See Figure 10 for structures of all species.

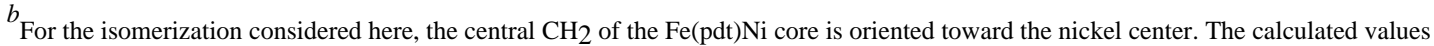
corresponding to the cases where the same $\mathrm{CH}_{2}$ is oriented toward the iron center are provided in Table $\mathrm{S} 9$.

${ }^{c}$ The potential energy surface was found to be relatively flat along the isomerization pathway, leading to relatively small imaginary frequencies for the TSs. 